NBER WORKING PAPER SERIES

\title{
PRIVATIZING R\&D: PATENT POLICY AND THE COMMERCIALIZATION OF NATIONAL LABORATORY TECHNOLOGIES
}

\author{
Adam B. Jaffe \\ Josh Lerner \\ Working Paper 7064 \\ http://www.nber.org/papers/w7064 \\ NATIONAL BUREAU OF ECONOMIC RESEARCH \\ 1050 Massachusetts Avenue \\ Cambridge, MA 02138 \\ April 1999
}

\begin{abstract}
Presented at the NBER Conference "The Patent System and Innovation" funded by the Alfred P. Sloan Foundation via a grant to the NBER Project on Industrial Technology and Productivity, and by the Harvard Business School's Division of Research. We thank Alper Afya and especially Petia Topalova for excellent research assistance. Helpful comments were provided by Linda Cohen, Rose Marie Ham, Sam Petuchoswki, and participants at the conference. Numerous officials at the DOE and the laboratories assisted in accessing data and contributed helpful insights, but especial thanks should go to Ray Barnes, Victor Chavez, Paul Gottlieb, Toni Joseph, Karena MacKinley, Giv Marguth, Ronald Meeks, Jeff Mobley, Bill Shepard, Warren Siemens, Claire Sink, and Walter Warnick.. Thanks should go as well to Buddy Beck, Clyde Frank, and Thomas Widmer. We appreciate Linda Cohen's help in accessing CRADA data. All errors are our own. The views expressed in this paper are those of the authors and do not reflect those of the National Bureau of Economic Research.
\end{abstract}

1999 by Adam B. Jaffe and Josh Lerner. All rights reserved. Short sections of text, not to exceed two paragraphs, may be quoted without explicit permission provided that full credit, including ${ }^{\circledR}$ notice, is given to the source. 
Privatizing R\&D: Patent Policy and the

Commercialization of National Laboratory Technologies

Adam B. Jaffe and Josh Lerner

NBER Working Paper No. 7064

April 1999

\section{ABSTRACT}

Despite their magnitude and potential economic impact, federal R\&D expenditures outside of research universities have been little scrutinized by economists. This paper examines whether the series of initiatives since 1980 that have sought to encourage the patenting and technology transfer at the national laboratories have had a significant impact, and how the features of these facilities affected their success in commercialization. Employing both case studies of and databases about the U.S. Department of Energy's laboratories, we challenge much of the conventional wisdom. The policy changes of the 1980 s had a substantial impact on the patenting activity by the national laboratories, which have gradually reached parity in patents per R\&D dollar with research universities. Using citation data, we show that, unlike universities, the quality of the laboratory patents has remained constant or even increased as their numbers have grown. The cross-sectional patterns are generally consistent with theoretical suggestions regarding the impact and determinants of the decision to privatize government functions.

Adam B. Jaffe

MS 021

Brandeis University

Waltham,MA 02554-9110

and NBER

ajaffe@nber.org
Josh Lerner

Harvard Business School

Morgan Hall, Room 395

Cambridge, MA 02163

and NBER

jlerner@hbs.edu 


\section{1) Introduction}

The United States government is by far the single largest performer and funder of research and development in the world. Between 1941 and 1997, the U.S. government spent $\$ 63$ trillion (in 1997 dollars) on $R \& D$, just under one-half of the total amount undertaken in the United States (see Figure 1). In 1993, the government's R\&D expenditures represented about $18 \%$ of the total funding of $R \& D$ in the major industrialized countries [National Science Board, 1998].

These expenditures, despite their magnitude and their potentially profound impact on productivity and growth, have attracted surprisingly little scrutiny by economists. While one environment in which federally funded research takes place, the research university, has been extensively studied,' it accounts for a relatively small percentage of overall funding. (As Figure 2 depicts, between 1955 and 1997, only 24\% of the total federally funded $R \& D$ performed in non-corporate settings took place in academic institutions.) The majority of these activities took place in laboratories owned by such agencies as the Departments of Defense and Energy, the National Aeronautics and Space Administration, and the National Institutes of Health. R\&D activities in this arena have attracted little academic scrutiny. ${ }^{2}$

Lending particular urgency to such research is the interest shown by policymakers, both in the U.S. and abroad, in increasing the role of government-owned laboratories in the technology commercialization process. Beginning in 1980, a series of legislative initiatives and executive orders in the U.S. have sought to encourage the patenting and the licensing of federally owned technologies, as well as the formation of cooperative arrangements between laboratories and private firms. These challenges have been particularly pressing at the laboratories devoted to national defense, whose primary historical mission of designing and testing nuclear weapons has been rendered largely obsolete by world events. Similar efforts have been launched in many other nations.

\footnotetext{
1 Examples include Nelson [1959], Jaffe [1989], and Henderson, Jaffe, and Trajtenberg [1998]. See also Stephan [1996], and the references cited therein.

2 Most of the academic literature has consisted of case studies of particular facilities [two thoughtful examples are Markusen and Oden, 1996, and Ham and Mowery, 1998] and surveys of potential or actual users of laboratories [e.g., Bozeman and Crow, 1991, Roessner and Wise, 1993, and Berman, 1997].
} 
This paper examines whether the statutory changes of the 1980s have had a significant impact on technology transfer from the national laboratories. We study the subset of federally funded research and development centers (FFRDCs) owned by the U.S. Department of Energy (DOE). These include some of the largest R\&D laboratories in the country, such as the Lawrence Livermore, Los Alamos, and Sandia facilities. We employ a series of databases developed by DOE not hitherto examined by academics to explore how patenting, the utilization of these patents by industry, and other technology transfer activities have shifted in response to these legislative changes.

In addition to examining shifts in the overall level of technology transfer activities, we also explore how the heterogeneous features of these facilities affect their success in commercialization. These laboratories differ from each other in at least three critical respects. First, the quality of the laboratories' technology may differ. This may partially reflect the nature of the laboratories' missions: those specializing in basic science or defense-related technologies, for instance, may have fewer technologies ripe for commercialization. It may also reflect the breadth of the laboratories' activities. In particular, numerous studies have contended that laboratories that engaged in extensive diversification outside of their core mission suffered a deterioration in R\&D quality. In addition, some facilities may have had excellent technologies, but may have been unable to commercialize them due to a lack of understanding about the technology transfer process.

Second, the facilities differ in nature of the political problems that commercialization efforts are likely to face. The conditions under which contractors should be permitted to patent and license federally funded technologies remains highly controversial. $^{3}$ Research on privatization suggests the resistance to such changes will vary with the circumstances of the parties. Across the laboratories, the relationships between the contractors assigned to run the facilities and the Department of Energy differ

\footnotetext{
${ }^{3}$ One example is the 1998 controversy that stemmed from a reexamination proceeding by the U.S. Patent and Trademark Office concerning two patents covering low-power radar. One patent had been awarded to a small Alabama company, the other to Lawrence Livermore National Laboratory. Before the patent hearing was even held, Alabama Representative Robert "Bud" Cramer requested that investigations of Livermore's technology transfer activities be undertaken by three congressional committees. Cramer also proposed legislation that would have restricted future collaborations between DOE FFRDCs and the private sector.
} 
significantly. Efforts to encourage transfers of knowledge to the private sector are likely to have elicited mixed reactions, depending on the circumstances of the contractor.

Finally, the locations of the facilities are highly disparate. Some FFRDCs are located near population centers with extensive innovative and entrepreneurial activities, while others are in highly remote areas. An extensive literature has documented the regional aspects of knowledge spillovers, which might suggest that the ability of laboratories to have commercial impacts might be quite different.

The results challenge some of the conventional wisdom about these laboratories, as reflected in government studies and press accounts. Far from having no impact, the policy changes of the 1980s appear to have had a substantial impact on the patenting activity by the national laboratories. While at the beginning of this period, the laboratories had considerably fewer patents per R\&D dollar than the average university, today they are about equal. Even more impressive is the evidence from the citations in other patents, a proxy for their importance. While the recent increase in university patenting has been accompanied by a substantial decline in the quality of the awards (as measured by the number of citations they receive), the quality of the laboratory patents has remained constant or has slightly increased. These results suggest the organizational structure of the government-owned contractor-operated model used at DOE laboratories may be far more credible than critics have suggested.

The relatively small number of DOE laboratories, combined with limited variation over time for each lab, makes it difficult to draw strong conclusions about how the different laboratory environments and organizational structures affect the technology transfer process. But several findings can be highlighted. First, consistent with claims that the diversification led to a degradation of quality of the laboratories' $R \& D$, it appears that the greatest commercial activity has derived from laboratories that have remained focused. Second, facilities with a turnover of contractors, when pressures from parties resistant to exclusive licensing are likely to have been lowest, have had greater success in accelerating their rate of commercialization. These effects are present when both patent citations and the extent of cooperative research are used as indicators of technology transfer. 
In addition to exploring an important but little-explored source of $R \& D$, this paper contributes to the literature on transfers from public to private ownership. While the underlying activities and the measures of performance are quite different, the results are consistent with numerous studies of privatized firms [reviewed in D'Souza and Megginson, 1998] that show transfers from public to private ownership to have a significant impact on performance. The results are also consistent with the smaller literature on the decision to privatize [e.g., López-de-Silanes, Shleifer, and Vishny, 1997], which emphasizes the extent to which political considerations can serve as a barrier to the transfers of ownership and/or control.

The plan of this paper is as follows. In Section 2, we provide some background information on government patent policy and the national laboratories. Relevant theoretical literature is summarized in Section 3. Section 4 presents two brief case studies of particular laboratories. The construction of the data set is described and the analysis presented in the Section 5. The final section concludes the paper.

\section{2) Patent Policy and the National Laboratories}

\section{a) Patent Policy and Federally Funded R\&D}

A substantial literature discusses federal policies towards the patenting and commercialization of the innovations whose development it has funded [Cohen and Noll, 1996]. ${ }^{4}$ Even a casual review of these works, however, makes clear how little the debate has changed over the decades. Many advocates have consistently called for government to take title to innovations that it funds, in order to insure the greatest diffusion of the breakthroughs. Others have argued for a policy of allowing contractors to assume title to federally funded inventions, or alternatively allowing the exclusive licensing of these discoveries.

While questions concerning the federal government's right to patent the results of the research it funded were the subject of litigation and Congressional debate as early as the $1880 \mathrm{~s}$, the debate assumed much greater visibility with the onset of World War II. The dramatic expansion of federal R\&D effort during the War raised questions about the

4 This issue was the topic over forty congressional hearings and reports and four special commissions between 1940 and 1975 [U.S. Energy Research and Development Administration, 1976]. Three historical overviews of the debates are Forman [1957], Neumeyer and Stedman [1971], and Hart [1998]. 
disposal of the rights to these discoveries. Two reports commissioned by President Roosevelt reached dramatically different conclusions, and framed the debate that would follow in the succeeding decades.

The National Patent Planning Commission, an ad hoc body established shortly after the Pearl Harbor attack to examine the disposition of the patents developed during the War, opined:

It often happens, particularly in new fields, that what is available for exploitation by everyone is undertaken by no one. There undoubtedly are Government-owned patents which should be made available to the public in commercial form, but which, because they call for a substantial capital investment, private manufacturers have been unwilling to commercialize under a nonexclusive license [U.S. House of Representatives, 1945, p. 5].

A second report, completed in 1947 by the Department of Justice, took a very different tack. Rather, it argued that "innovations financed with public funds should inure to the benefit of the public, and should not become a purely private monopoly under which the public may be charged for, or even denied, the use of technology which it has financed" [U.S. Department of Justice, 1947, p. 2]. The report urged the adoption of a uniform policy forbidding both the granting of patent rights to contractors and exclusive licenses to federal technology in all but extraordinary circumstances. Over the ensuing 30 years, federal patent policy vacillated back and forth between these two views [Forman, 1957; Neumeyer and Stedman, 1971].

Beginning in the 1980 s, policy seemed to shift decisively in favor of permitting exclusive licenses of publicly-funded research to encourage commercialization. The Stevenson-Wydler Technology Innovation Act of 1980 (P.L. 96-480) explicitly made technology transfer a mission of all federal laboratories and created a variety of institutional structures to facilitate this mission. Among other steps, it required that all major federal laboratories establish an Office of Research and Technology Applications to undertake technology transfer activities. At about the same time, the Bayh-Dole Act allowed academic institutions and non-profit institutions to automatically retain title to patents derived from federally funded R\&D. The act also explicitly authorized government-operated laboratories to grant exclusive licenses on government-owned 
patents. These two acts were follow by a series of initiatives in the $1982-89$ period that extended and broadened their reach. ${ }^{5}$

This wave of legislation did not resolve the debate concerning the extent to which ownership of government-funded R\&D ought to be transferred to private sector entities. Congressional and agency investigations of inappropriate behavior during the commercialization process-particularly violation of fairness of opportunity and conflict of interest regulations during the spin-out and licensing process-continued to be commonplace. CRADAs and other efforts to work with large companies have remained controversial. Nonetheless, this series of legislation represented a decisive shift in the long debate on government patent policy.

\section{b) The DOE FFRDCs ${ }^{6}$}

Many of the DOE FFRDCs, also known as national laboratories, had their origins in the Manhattan Project during World War II. The development of the atomic bomb required the establishment of a number of specialized facilities, many of which were located in remote areas due to concerns about safety and security. After the War, these facilities were placed under the control of outside contractors, some of whom are universities and some private firms. It was hoped that these Government-OwnedContractor-Operated facilities ("GOCOs") would be insulated from political pressures, and would be better able to attract and retain talented personnel because they did not have to conform to civil service rules.

A series of reports over the past several decades, however, have highlighted the limitations of the GOCO model. ${ }^{7}$ Repeated reports have highlighted the same problems concerning the management of the laboratory system: (1) the desired political independence has never been achieved, with DOE imposing extensive regulatory

\footnotetext{
${ }^{5}$ In 1986, the Federal Technology Transfer Act allowed government-operated facilities to enter into cooperative R\&D arrangements (CRADAs) with industry (P.L. 99-502), as well as to grant outside collaborators the title to any invention that resulted. In 1989, the National Competitiveness Technology Transfer Act of 1989 (P.L. 101-189) extended the 1986 legislation enabling the formation of CRADAs to the GOCO facilities.

6 This abbreviated history is based in part on Branscomb [1993], U.S. Office of Technology Assessment [1993], and U.S. General Accounting Office [1998]. The interested reader is referred to these sources for more detailed accounts.

7 These critiques date back at least as far as the "Bell Report" prepared by the Office of Management and Budget in 1963. Two clear expositions of these problems are found in the "Packard Report" [White House Science Council, 1983] and the "Galvin Report" [Task Force, 1995].
} 
guidelines that limit the flexibility of contractors; (2) duplication and redundancy across the laboratories; and (3) unfocused diversification of the facilities into new activities, particularly after funding for the core nuclear activities declined. As a recent synthesis of these studies by the U.S. General Accounting Office [1998] noted, "despite many studies identifying similar deficiencies in the management of DOE's laboratories, fundamental change remains an elusive goal."

\section{c) Patent Policy and the DOE FFRDCs}

Prior to 1980 , the laboratory contractors were assigned few patents and exclusive licenses of were rare (see Table 1$)^{8}$ Although DOE policy began to change after the legislative changes of the 1980s, a number of accounts [e.g., U.S. Office of Technology Assessment, 1993] suggest that DOE's response was delayed until the period between 1986 and 1989.

Many observers also suggest that the implementation at the DOE of the 1980s reforms was problematic. Critics have attributed this to two factors. First, the problems with the laboratory structure in general noted above led to resistance to these reforms. ${ }^{9}$ Second, the fundamental conflict between the commercial need for clear private property rights in the form of exclusive licenses and the broader goals of public research seemed particularly acute at these facilities. In many cases, spin-out firms or cooperative partners were not able to obtain exclusive licenses to DOE patents, or were only able to do so after delays of many years. Some licenses were subsequently challenged as violations of conflicts of interest or fairness of opportunity rules in lawsuits by competitors or in Congressional hearings [e.g., Markusen and Oden, 1996]. DOE radically scaled back its

8 It should be acknowledged that even within the earliest contracts granted by the Manhattan Engineer District during the War was a recognition that contractors should control non-atomic innovations that were only tangentially related the government's mission. In practice, however, the government made very little use of this right to grant ownership to national laboratory contractors or to license its patents on an exclusive basis. [For a discussion, see U.S. Energy Research and Development Administration, 1976.]

${ }_{9}^{9}$ One illustration is the process through which proposed cooperative agreements with industry were evaluated. While in many agencies, laboratory directors were allowed to implement CRADAs with limited headquarters oversight or regulatory requirements, DOE introduced a three-part review process. CRADA proposals were reviewed at the laboratory level, followed by a centralized screening by the headquarters program offices (typically on an annual basis), followed by the negotiation of a contract and a work statement (in which laboratory, field office, and program office personnel are all involved). Not surprisingly, during the period when DOE was actively seeking new CRADAs, the level of activity was lower than in other agencies and the time from inception to signing much longer [U.S. General Accounting Office, 1993]. 
CRADA program in 1995 and 1996 after Republican congressmen questioned whether they represented "corporate welfare" [Lawler, 1996].

These difficulties had a negative impact on corporations or venture capitalists' willingness to invest in these projects. Reviews of technology transfer activities at the national laboratories have almost universally highlighted the lack of progress in this regard, particular when contrasted to universities. ${ }^{10}$

\section{3) Theoretical Insights}

\section{a) Does Government Patent Policy Matter?}

Economic theory suggests a variety of reasons for suggesting that public ownership may have different effects than private ownership:

- One such framework is suggested by Alchian [1965], who argues that a central difference between private and public ownership is the ability to reapportion ownership. If a private company is performing less well than its peers, and a small number of individuals believe they can create value through a shift in management policy, they can (at least hypothetically) rapidly assemble a controlling position in the firm and implement those changes. Since the shares of government owned firms are not publicly traded, effecting these types of changes might be difficult.

- Second, arguments for the superiority of private ownership relate to the difficulty of providing high-powered incentives to and intensive monitoring of managers in state-owned firms [Vickers and Yarrow, 1988]. Evidence suggests that privatization is often associated with an acceleration of managerial turnover [e.g., Barberis, et al., 1996].

- A third argument, highlighted by Shleifer and Vishny [1994], relates to the detrimental effects of political control over economic activity. Politicians are unlikely to directly benefit from the profitability of a state-controlled enterprise, and may be subject to many pressures from lobbyists and campaign contributors to encourage actions that do not maximize an enterprise's value. As a result, they may push for choices that are far from the efficient ones. In a setting where multiple politicians have control rights and seek to maximize their own particular objective functions, the distortions can be particularly severe.

\footnotetext{
${ }^{10}$ For instance, U.S. Office of Technology Assessment [1993] compares the technology licensing revenues of the Massachusetts Institute of Technology to DOE FFRDCs. While MIT in 1996 had less than $12 \%$ of the collective R\&D expenditures of the thirteen leading FFRDCs, it had nearly three times the revenues from its licensing activities in 1997 ( $\$ 21.2$ million $v s$. $\$ 7.5$ million). It should be noted, however, that licensing revenues is a "lagging indicator": much of the licensing revenues may be generated by technologies licensed a decade or longer ago.
} 
These claims are generally supported by the recent empirical literature on privatization, which suggests that shifts from public to private ownership are associated with an improvement in operations [e.g., Megginson, Nash, and van Randerbough, 1997].

In the same spirit, it might be contended that assigning the ownership of publicly funded patents to the government is less efficient than assignments to a private firm. Providing both control and cash flow rights over intellectual property to a single entity that is free of political interference should lead to optimal decisions as to how the technology is commercialized.

\section{b) What Explains Cross-Sectional Variations?}

In addition to suggesting the general effects of moving property rights into the private sector, theory also suggests factors that would be likely to affect the differential success of such a policy shift across different laboratory environments. First, some kinds of research are inherently more difficult to commercialize. Laboratories that are particularly tied to national security issues or devoted to fundamental scientific research are less likely to have commercialization opportunities. Second, as suggested above, laboratories that have pursued unfocused diversification efforts may have lower quality research; this echoes the literature on adverse effects of diversification in the corporate setting [Lang and Stultz, 1994; Scharfstein and Stein, 1997]. If diversification reduces research quality, it would lead to less "product" to transfer.

Organizational factors are also likely to matter. As discussed above, the 1980 Bayh-Dole reforms gave a great degree of flexibility to universities to license and spin out new technologies. Many academic institutions exploited these changes by building up technology licensing offices and aggressively marketing new technologies [Henderson, Jaffe and Trajtenberg, 1998]. FFRDCs whose prime contractors were universities may have benefited from this know-how to make their technology transfer activities more effective.

The nature of the contractor and its relationship with the DOE might have had an important influence on what Boyko, Shleifer and Vishny [1995] characterize as the "depoliticalization process" inherent in transfers from public to private control. It might be thought that depoliticization was more difficult at organizations where the prime contractor had a long-standing presence at the laboratory. Efforts to encourage exclusive 
licensing have been highly controversial within the DOE. A particular source of resistance has been the DOE field offices, where in many cases the staff has questioned the desirability of senior management's efforts to change technology transfer policies. (One motivation for these concerns may the loss of control inherent in the delegation of a great deal of discretion to contractors' technology licensing offices.) A new contractor typically brings in new staff when he receives an award to run a facility. After time, however, this staff may develop close working relationships with DOE officials in the local field office. Consequently, resistance to residual efforts to assert control by the Department staff may be the greatest in a setting where there is a new contractor. This would be consistent with the evidence concerning the decision to contract out of municipal services: in settings where municipal unions have greater influence (e.g., when public employees are not restricted from participating in political activities), there is much greater resistance to privatizing government services [López-de-Silanes, Shleifer, and Vishny, 1997].

Finally, one might expect that geographic location would affect the success of technology transfer. Recent work has shown that knowledge spillovers tend to be geographically localized, particularly within geographic areas [Glaeser, et al., 1992; Jaffe, Trajtenberg, and Henderson, 1993]. This concentration of knowledge spillovers has implications for the relative level of technology transfer at the national laboratories because these facilities are located in very different areas. Some facilities are located far from any major metropolitan area, while others are nearby a major metropolis. If it is easier to transfer to nearby firms, the laboratories that are located in remote areas will have more trouble finding recipients. This disadvantage could be amplified by the concentration of venture capital, the primary mechanism for funding for privately held, high-technology companies. Venture organizations are highly geographically concentrated, with over half the funds based in California and Massachusetts. [Gompers and Lerner, 1999, provide a detailed description.] Furthermore, venture capitalists tend to be highly localized in their investment patterns: over half the venture-backed firms have a venture investor who serves as a board member based within 60 miles of the firm [Lerner, 1995]. Thus, even if laboratories in remote areas with little venture capital 
activity do generate spillovers to nearby companies, the local firms may be unable to access the needed financial and other resources to profit from them. ${ }^{11}$

\section{4) Two Case Examples}

We briefly illustrate these challenges through a discussion of two laboratories, Lawrence Livermore National Laboratory (LLNL) and the Idaho National Engineering and Environmental Laboratory (INEEL). These facilities are in some respects very different. The former has DOE's Office of Defense Programs as its primary funder, has an academic institution as a prime contractor, and is located in the San Francisco Bay Area. The latter is funded primarily by DOE's Office of Environmental Management, has a private corporation as the prime contractor, and is located in a remote area of eastern Idaho. But both facilities have overcome considerable challenges to develop technology transfer efforts that in many respects represent "best practice" among the DOE FFRDCs. LLNL and INEEL have led the laboratories in the level of licensing revenue and spinout companies respectively.

\section{a) Lawrence Livermore National Laboratory}

Lawrence Livermore is one of the three very large DOE FFRDCs that has historically specialized in nuclear weapons research. LLNL was established in Livermore, California in 1952. The University of California has operated this facility from its inception. From the first, LLNL had a strong emphasis not only on the engineering of thermonuclear weapons, but on related fundamental science. It was an aggressive user of the newest computational technology: for instance, the first facility at Lawrence Livermore was a building to house the then-new UNIVAC computer, which was needed for the complex calculations in the weapons design process. As in other facilities, there has been a broadening of the laboratory's mission over time into such areas as non-nuclear energy, biomedicine, and environmental science.

The evolution of the technology transfer function at the laboratory has similarly featured both continuity and change. At least since the 1960s, the laboratory has had

11 Some supporting evidence for this claim is found in Lerner's [1999] analysis of the federal Small Business Innovation Research program, an award program for small high-technology companies. Awardees that were located in regions with substantial venture capital activity did significantly better than a matching set of non-awardees. The awards had no effect, however, in regions without venture capital activity. 
strong relationships with the computer and laser industries. Advances to the state-of-theart developed at the laboratory were often transferred to private firms or developed by companies in response to laboratory requests, in order to generate a production-scale source of equipment, instrumentation, or components for the larger experimental facilities. In many cases, the prototypes were cooperatively developed by private sector and laboratory researchers. A significant number of these innovations eventually found their way into the civilian market. The laboratory's motivation for engaging in this activity, however, had little to do with concerns about "technology transfer." Rather, the staff involved the private sector because procuring equipment from outside vendors was often more efficient than manufacturing the devices at the laboratory. The relationships with vendors were highly informal. The LLNL made virtually no effort to claim intellectual property holdings, and in many cases, their partners did not seek to patent the discoveries either.

A formal technology transfer office was established at LLNL after the DOE issued the implementing regulations for the Stevenson-Wydler Act in 1982. The office was initially modestly funded, with little internal or external visibility. There was a dramatic increase in activity, however, after the passage of the National Competitiveness Technology Transfer Act of 1989. In particular, the DOE established a central program (later known as the Technology Transfer Initiative) primarily to fund CRADAs between the laboratories and companies. With this influx of funding--in 1994 alone, LLNL received $\$ 55$ million for this purpose from the DOE-the technology transfer office (now known as the Industrial Partnerships and Commercialization, or IPAC, Office) rapidly increased in size. During this relatively brief era, LLNL collaborated with industry partners to carry out almost two hundred mostly small, jointly funded projects spanning a broad spectrum of technology areas. A great deal of effort was devoted to writing proposals, attending trade shows, and hosting visiting delegations.

This period left two important legacies. First, the laboratory established a few important relationships, such as with semiconductor manufacturers, that would have ongoing importance. Second, an infrastructure was developed to better interact with industry: e.g., the ability to fairly quickly enter into agreements, to protect proprietary information, and to allocate the intellectual property generated in the agreements. As 
time progressed, however, laboratory officials felt that such a large number of partnerships in relatively unfocused technology areas were distracting personnel from the facility's primary programs.

In 1995, the U.S. Congress, whose control had just switched to the Republican Party, dramatically cut funding for the Technology Transfer Initiative. The DOE followed suit with additional cuts. This triggered a shift at LLNL back to its original focus on only undertaking industrial partnerships related to its mission. Projects with outside companies that were only tangentially related to the laboratory's mission were largely terminated. As a result, LLNL as of November 1998 had a few very large technology transfer efforts, a vastly reduced number of smaller R\&D projects, and a growing number of licenses. On the one extreme was the CRADA at LLNL and two other laboratories to produce semiconductors through extreme ultraviolet lithography, to which Advanced Micro Devices, Intel, and Motorola were contributing \$250 million over three years. At the other extreme were numerous licenses of laboratory technology, primarily with small high-technology firms. (See Panel A of Table 2 for a summary of LLNL's technology transfer activities.)

Lawrence Livermore's success in licensing relative to the other laboratories had been facilitated by its strong ties to the University of California, as well as its physical proximity to the companies and financiers in the Bay Area. The IPAC office frequently interacted informally with the licensing staff at the University's Office of Technology Transfer. At the same time, the office faced challenges that their university-based peers did not. In particular, the IPAC office did not automatically receive title to patents (as universities have since the passage of Bayh-Dole). Rather, the staff had to formally request waivers from the $\mathrm{DOE}$ on a case-by-case basis, which could be a lengthy process. Second, the office faced much greater scrutiny of its actions under fairness of opportunity and conflict of interest rules. As a result of this scrutiny, the IPAC extensively publicized potential licensing opportunities and took great care to avoid these problems, including often encouraging prospective licenses to accept non-exclusive licenses.

LLNL's licensing activities and revenues rose dramatically in the 1990s. But it faced a continuing challenge posed by its diffuse and changing mandate from the U.S. Congress. For instance, the directives to the laboratories to transfer technology in a way 
that benefits the U.S. economy, to insure fairness of opportunity, and to avoid competition with the private sector were interpreted very differently by various members of Congress. Anticipating how these concerns would evolve over time, and which transactions might be seen as problematic in retrospect, was not easy. Compounding this factor was the fact that as the laboratory's technology transfer effort had become more visible, it had been increasingly a target for complaints and scrutiny, as the instance discussed in Footnote 3 illustrates.

\section{b) Idaho National Engineering and Environmental Laboratory}

Shortly after World War II, the federal government sought an isolated location to test nuclear reactors. The predecessor to INEEL, the National Reactor Testing Station, was established in 1949 on an 890 square mile site in the southeastern Idaho desert that had been used as a practice bombing range during World War II. Over the years, the laboratory undertook major research programs seeking to develop prototypes of and to test reactors for both naval vessels and (until 1961) airplanes. Another important activity was the reprocessing of the large amounts of uranium generated by these reactors. Unlike LLNL, which has had only one contractor from its inception, INEEL was managed by a series of contractors over the years. These included Aerojet Nuclear (a subsidiary of General Tire) and a consortium including EG\&G and Westinghouse Electric (between 1977 and 1994).

As the Management and Operation Contract for the laboratory neared completion in 1994, it became clear that a major emphasis in selecting the next contractor would be a commitment to technology transfer activities. INEEL represented a major employer in the State of Idaho. Local politicians had argued that more efforts were needed to soften the impacts of employment and funding cutbacks at the laboratory by encouraging the creation of spinout firms. The minimal level of technology transfer activity in this period can be seen in Panel B of Table 2: for instance, in FY 1992, there were no spinouts and the laboratory generated only seven thousand dollars in licensing revenue. ${ }^{12}$ While EG\&G rapidly increased its signing of CRADA and licensing agreements in response to

12 INEEL did not experience the same increase in CRADA activity in the late 1980s and the early 1990s that LLNL did, because much of the funding for these efforts was provided by DOE's Office of Defense Programs. Because INEEL received only very limited funding from Defense Programs, the impact of this initiative was much smaller than at LLNL. 
these pressures, the new contract was awarded instead to a consortium led by a subsidiary of the Lockheed Corporation (the company's name was changed to Lockheed Martin in 1995). Among the participants in the consortium was Thermo Electron Corporation, a Massachusetts company with a history of spinning out new technology businesses into publicly traded entities.

The contract included a variety of features to help insure the technology transfer activities would be taken seriously. The contractors committed to provide entrepreneurial training to laboratory researchers who were prospective leaders of spinout firms. Thermo Electron committed to establish a $\$ 10$ million venture capital fund to be made available to finanice new businesses spinning out from the laboratory. Perhaps most importantly, Lockheed signed a contract where its reward would be a function of its technology transfer activity. In particular, Lockheed agreed to forego several millions dollars from its annual fee for managing the laboratory. Instead, it received a share of fees and royalties, which increased with the cumulative amount of payments received over the course of the five-year contract. Until the first $\$ 1$ million of licensing payments was received, the firm would receive $20 \%$ of the revenue (the remainder being divided between the researcher and the federal government). For the next $\$ 1$ million, Lockheed would receive $30 \%$, and thereafter it would receive $35 \%{ }^{13}$

In order to implement this contract, the new contractor undertook a variety of changes to the structure of the technology licensing office as well. Lockheed recruited individuals who had held senior business development positions with companies such as General Motors and IBM, as well as licensing account executives with private sector sales and marketing experience. In addition, the company organized industry focus teams, with the responsibility to establish relationships with and market INEEL capabilities and technologies to companies in specific industries. As Panel B of Table 2 indicates, both spinout and licensing activity increased dramatically in response to these activities. The increase in spinout activity was particularly noteworthy: in fiscal year 1997, INEEL accounted for 7 out of the 19 spinouts from DOE FFRDCs.

\footnotetext{
13 While universities, who under the Bayh-Dole Act own the patents from federally funded research at their facilities, routinely receive royalties from licensing activities, this provision was a first among FFRDC management contracts [U.S. General Accounting Office, 1996a].
} 
At the same time, the implementation of this plan faced unexpected difficulties. One was the extent of the barriers to spinning out of technologies from INEEL. Laboratory researchers seeking to obtain an exclusive license to a technology they had worked on faced an exhaustive and slow review process. Even when the entrepreneurs overcame concerns about fairness and conflict of interest provisions, in some instances they believed that the laboratory's demands for payments and royalties were excessive, given the early stage of the technologies. Some felt that the management contract provided the contractor with incentives to license technologies to large corporations that could offer larger up-front payments than start-ups. ${ }^{14}$ In addition, entrepreneurs faced barriers raising capital once they had exhausted the seed funds that the small Thermo Electron fund and other local investors could provide

Despite the considerable success of the INEEL effort, the future of the effort was in doubt at the end of 1998. The DOE decided in September 1998 not to renew Lockheed's contract, but rather to put the contract once again up for bid. While the DOE review rated Lockheed's technology transfer effort highly, the agency raised concerns about the contractor's record in worker safety and its failure to undertake an environmental clean-up project at INEEL for an agreed-upon price. While the DOE made it clear that it expects the next contractor to be committed to technology transfer, whether the next contractor will be successful as Lockheed in growing the technology transfer activities remained uncertain.

\section{5) Statistical Analysis}

\section{a) The Data Set}

A point raised in many assessments of the national laboratory system [e.g., Task Force, 1995, Section VII.C.5] is the extreme difficulty in obtaining data, particularly in

\footnotetext{
14 As of the end of FY 1997, Lockheed had received a total of about $\$ 130,000$ from its share of the royalties, only a few percent of the amount foregone in fees. At the same time, it is important to acknowledge the dilemma that Lockheed officials faced when considering licensing to prospective startups. In order to assess whether a start-up was the entity with the greatest chance of commercializing an INEEL technology, the technology transfer officials typically requested that it provide a business plan and show proof of adequate financing. But in many cases, entrepreneurs found that (particularly in a state with as little financing of small high-technology firms such as Idaho) that obtaining a license to the technology was a prerequisite to be considered for financing. Another challenge was the difficulty of identifying people with the entrepreneurial business talents to complement the laboratory scientists and engineers in a spin-out.
} 
regard to technology transfer activities. This is at least partially a reflection of the DOE's complex management structure discussed above. As a result, we have constructed a data set from a wide variety of sources.

We constructed a sample of 23 FFRDCs owned by the DOE and active between 1977 and 1997, derived from Burke and Gray [1995] ${ }^{15}$ and U.S. National Science Foundation [various years]. Two of these commenced operations as FFRDCs during this period, while six of these were decertified for various reasons during this period.

\section{i) General Information}

Information collected for each facility included:

- historical information such as dates of establishment or decertification, and identity of contractor over time [Burke and Gray, 1995; U.S. General Accounting Office, 1996b; facility web sites; news stories in LEXIS/NEXIS].

- regional characteristics such as the distance to the nearest standard or consolidated metropolitan statistical area (SMSA or CMSA), the population and education level of that area, and venture capital activity in the state [U.S. Bureau of the Census; Venture Economics' Venture Intelligence Database (described in Gompers and Lerner, 1999)].

- overall laboratory budget level and funding sources. ${ }^{16}$

- annual R\&D expenditures at each FFRDC between 1981 and 1995 [National Science Board, 1996; U.S. National Science Foundation, 1998].

- the number of new CRADAs formed annually between 1991 and 1994 under the aegis of three program offices (Defense Programs, Energy Efficiency, and Energy Research), and all CRADAs formed in 1995 and $1997 .{ }^{17}$

- miscellaneous data about a variety of technology transfer activities [U.S. Department of Energy, Office of Defense Programs, 1998; U.S. Department of Energy, Office of the General Counsel, 1998]. ${ }^{18}$

Table 3 provides summary data on these facilities.

\footnotetext{
${ }^{15}$ References to sources only cited in Section 5(a) are included in the "Data Sources" listing, and not in the main "References" listing.

${ }_{16}$ While the DOE does not prepare an annual yearbook of activities at the laboratories, we obtained general statistical data on the laboratories' funding levels and sources in three fiscal years-1979, 1988, and 1995-from two special compilations [U.S. Department of Energy, 1990; U.S. Department of Energy, Laboratories Operations Board, 1996].

17 The sources of the CRADA data are U.S. Department of Energy [1995], Technology Transfer Business [1998], and U.S. Department of Energy, Office of the General Counsel [1998]. The three program offices with complete data accounted for $94 \%$ of all DOE outputs related to commercial product development in fiscal year 1992 [U.S. General Accounting Office, 1994, Appendix V, Table 2] and 82\% of all CRADAs between fiscal years 1990 and 1992 [U.S. Office of Technology Assessment, 1993, Table 4-1].
} 


\section{ii) Measures of Patenting Activity}

The final set of variables measures the number of and citations to patents derived from laboratory research. This section reviews the difficulties associated with measuring patenting activity at the FFRDCs, the DOE database that allows us to address these problems, and the issues associated with the use of the database.

Patent awards from DOE research are sometimes assigned to the Department; at other times when waivers are granted, they are assigned to the contractors. There is no single identifier in the patent application that allows one to identify DOE-funded patents: e.g., it is difficult to distinguish from the text of a patent assigned to the University of California whether it was derived from work at the University's Berkeley campus or Lawrence Livermore. To address this problem, we employ a database compiled by the DOE's Office of Scientific and Technical Information [1998] of all patents to emerge from DOE laboratories since 1978. The database, which consists of 6479 U.S. patents awarded by the end of 1996, contains all patents produced from laboratory-produced research, regardless of the entity to which the patent is assigned. ${ }^{19}$

The file also has two major drawbacks. First, it contains awards assigned to entities that have never operated a DOE FFRDC. It is likely that some of these are patents derived from CRADAS between a laboratory and another entity. Others are derived from other contractor-operated facilities that are not designated as FFRDCs. Some of the patents, however, are apparently not derived from DOE-funded research but are merely in an area of interest to the Department. A second difficulty is that the database does not provide any direct means to connect the patents to particular FFRDCs. Most, though not all, of the patents in the database are identified with a contract number that corresponds to the "Management and Operation" contract at the originating facility at the time of the patent award. These are identified through a database maintained by

\footnotetext{
${ }^{18}$ In both cases, the project staff made efforts to employ consistent definitions across the various facilities, but inconsistencies may remain. Much of the data are only available for the most recent period.

${ }_{19}$ In particular, it contains patents assigned to the contractor who operates a given laboratory. U.S. Patent and Trademark Office databases (as well as the NBER/Case Western Reserve database discussed below) identify patents assigned to the U.S. government and its agencies. They do not provide, however, any way to separate patents assigned to firms in their capacity as contractors operating government laboratories from those derived from the contractor's other research [see Jaffe, Fogarty, and Banks, 1998]. Of the patents we have included in our analysis, $42 \%$ was assigned to non-governmental entities.
} 
DOE's Office of Procurement and Assistance Management [1998] as well as personal communication with officials of this office.

The list of DOE patents was then merged with the NBER/Case Western Reserve patent database. This allows us to determine the patent class, application year, and the address of the inventor for each patent. We also identified all patents that cited these patents through the end of 1995 . Given these ambiguities, we followed the following procedure:

- first, every patent whose contract number in the database corresponds to a known Management and Operation contract was attributed to that FFRDC.

- second, every patent without a contract number whose assignee was the DOE and whose primary inventor lived in a SMSA where there was a DOE FFRDC was assumed to come from that laboratory.

- third, every patent without a contract number whose assignee was a laboratory contractor, and whose primary inventor lived in a SMSA where there was a DOE FFRDC run by that contractor, was assumed to come from that FFRDC.

- fourth, patents that could not be attributed to a specific FFRDC, but which most likely derived from DOE laboratory research, were used for aggregate analysis but were not included in the laboratory-specific analyses. These include patents with unidentified contract numbers, patents assigned by the patent office to DOE with inventors residing in SMSAs with multiple laboratories, and patents assigned to contractors with multiple laboratories in a given SMSA, with inventors residing in that SMSA. ${ }^{20}$

- all other patents in the database were not used in the analysis below.

Overall, of the 6479 patents in the DOE database, 3185 were attributed to particular DOE FFRDCs, 1771 were determined to be laboratory patents but were not attributed to any particular facility, and 1523 could not be determined to be derived from laboratory research and hence were ignored. $^{21}$ Our approach undoubtedly both includes some nonlaboratory patents and excludes some laboratory patents. Overall, we are probably undercounting laboratory patents. Many of the 1771 ignored patents have inventors

20 The most important example of the latter is the University of California, which operates both the Lawrence Livermore and Lawrence Berkeley laboratories in the Bay Area. The patents of these laboratories could be distinguished only when the contract number was reported. Approximately 100 patents assigned to the University, with inventors residing in the Bay Area, did not have contract numbers and so could not be attributed to either laboratory.

${ }^{21}$ Because the number of unattributable patents is falling over time-i.e., the probability of successfully attributing a patent is greater later in the period-if one ignored these patents, then we would overstate the upward trend. 
living in a SMSA in which there is a laboratory, but they are assigned to firms other than the contractor. It is likely that some of these derive from CRADAs, but we have no way to determine that and so have excluded them.

Throughout this paper, we date patents by the year of application, since that is when the research was likely to have occurred and the decision made to apply for the patent. The DOE patents database contains only those patents awarded through the end of 1996. Since it typically takes between one and two years to process a patent application, we seriously undercount applications made in the years after 1993.

Table 4 shows the patent totals for each of the 23 DOE FFRDCs. Many of the laboratories had no successful patent applications in 1977. By the end of the period, most made successful patent applications every year. (Note that four laboratories were decertified by 1992.) Not surprisingly, a handful of the larger laboratories contribute most of the patent applications filed in each year.

\section{b) Analyses of Overall Technology Commercialization Patterns}

As discussed above, the numerous statutory changes in the 1980 s were intended to foster the commercialization of federally funded R\&D. If successful, these changes should have increased the rate of patenting of laboratory discoveries and the utilization of these inventions by the private sector. To explore this question, we look at the time trend in patenting and the citations to these patents, as well as other measures.

Figure 3 shows that the number of successful DOE laboratory patent applications rose from about 200 in 1981 to over 450 by 1993 . (As noted above, the latter number is a slight underestimate, because some applications will have been granted after 1996.) Furthermore, this sharp increase in patenting has occurred in the face of declining real R\&D expenditures at the DOE FFRDCs. As shown in the figure, the increase began in 1988, shortly after the passage of the Federal Technology Transfer Act, and continued into the mid-1990s.

To put this increase in the "propensity to patent" in perspective, Figure 4 compares the patent-to-R\&D ratio for the DOE FFRDCs to a similar ratio for universities. $^{22}$ In the early 1980s, patents per dollar of FFRDC R\&D were considerably

${ }_{22}$ Total university research expenditures are from National Science Board [1998]. University patent totals are from the NBER/Case Western Reserve patents database. 
lower than in the universities, despite the fact that two-thirds of the university research was for basic research, which is presumably less likely to lead to patent awards. (The comparable figure for all federal FFRDCs is slightly over $40 \%$. The source of these tabulations is National Science Board [1998].) University patenting rose strongly through the 1980s, at least partially in response to the Bayh-Dole Act of 1980. But by the late 1980s, patenting (relative to R\&D spending) at the DOE FFRDCs was rising even faster. By 1993, the two sectors were comparable in terms of patents per R\&D dollar. While the lower share of basic research at the laboratories makes this somewhat of an unfair comparison, the relative performance of the DOE FFRDCs in the late 1980s and early 1990s was nonetheless remarkable. ${ }^{23}$

It has been shown that the dramatic increase in university patenting in the $1980 \mathrm{~s}$ was accompanied by an equally sharp decline in the quality of those patents, as measured by the citations received by those patents relative to all patents with the same technological characteristics and award year [Henderson, Jaffe, and Trajtenberg, 1997]. Before about 1985 , university patents on average were much more highly cited than other patents. This difference had disappeared by the late 1980s. The increase in university patenting appears to have come about largely by "lowering the threshold" for patent applications, resulting in many more patents of marginal significance.

To explore whether similar changes occurred at the DOE FFRDCs, we construct the "normalized" citation intensity for each laboratory in each year. To do this, we calculate the difference between the actual number of citations received per patent and the "reference" citation intensity. The reference citation intensity is the expected number of citations per patent that a portfolio of patents with the same technological classifications as those of the laboratory would receive, based on the citations received by all patents in a given technology class in a given year. This normalized intensity controls for differences across technology classes and time in the "propensity to cite," as well as for the impact of the truncation imposed by our lack of knowledge of citations that will occur after 1995.

\footnotetext{
${ }^{23}$ Unlike the declining trend of real R\&D expenditures in the DOE FFRDCs, university research spending was rising rapidly during this period. Thus, while the laboratories were "catching up" in terms of patents per dollar of research spending, the absolute number of patents was rising faster in the university sector.
} 
We also report in Figure 5 the trend in patenting. Here we employ not the aggregate count of patents derived from DOE FFRDCs, but rather a normalized series that controls for the shift in the overall "propensity to patent." In each technology class and in each year, we compute the ratio of the number of patents derived from the DOE laboratories to the total number of awards. The changes in this value, which is normalized to be 1.0 in 1981 , are plotted over time. During periods when the overall number of patent applications is falling, this normalization will make an increase in DOE patenting appear more dramatic, and vice versa.

Figure 5 shows a citation pattern in conjunction with increased patenting for laboratories that is very different from that found for universities. First, note that in contrast to the university patents, laboratory patents have historically been slightly less highly cited than other patents. ${ }^{24}$ It is striking, however, that the laboratory citation intensity did not decline in conjunction with the large increase in the propensity to patent after 1987. Whether we look at a simple average across the laboratories or an average weighted by the number of patents, the trend in citation intensity is upward. ${ }^{25}$ This trend, however, is not statistically significant. Thus, the kind of "digging deeper into the barrel" that characterized the increase in university patenting does not seem to have occurred at the DOE FFRDCs. While this clearly merits more study, the citation data are consistent with a process in which the laboratories produced more patents by reorienting their research towards new areas with greater commercial applicability, in keeping with the intent of the statutory changes.

It would also be desirable to look at other indicators of technology transfer. Unfortunately, we have only extremely limited and inconsistent data on other indicators of technology transfer, and very few measures, particularly over time, of laboratory

\footnotetext{
24 Jaffe, Fogarty, and Banks [1998] examined the citation intensity of patents assigned at issuance to the U.S. government. As noted above, their analysis excluded patents from the laboratories assigned to the contractors, but did include other agencies besides DOE. In that paper, the citation "inferiority" of federal patents was even more pronounced, but also showed some tendency toward reduction in the late $1980 \mathrm{~s}$.

25 The pattem is also similar if we look only at "non-self-citations." Non-self-citations exclude those citations in patents that are assigned either to the DOE or to the contractor that operates the laboratory from which the cited patent originated. The non-self-citation measure is "normalized" as well, following a procedure similar to that described above but only using non-self-citations to construct the reference portfolio. The fact that the normalized non-self-citation pattern over time is so close to the normalized total citation pattern means that the rate of self-citation to laboratory patents is similar, on average, to the rate of self-citation for all patents.
} 
policies and behaviors. In Section (d), we explore other measures of technology transfer in panel and cross-sectional analyses of the laboratories. Before turning to that, however, we undertake panel data regression analyses using patents and citations.

\section{c) Regression analyses using patent data}

The regression analysis covers the period from 1981 to 1993 (for the analysis of patenting) and 1977 to 1993 (for the analysis of patent citations). The first year of the analysis is determined by the limitations of DOE patent database, as well as by our desire to use R\&D at each FFRDC as an independent variable in the case of the patenting regressions. The final year of the analysis is determined by the problem of lengthy patent pendencies discussed above.

As dependent variables, we employ either the count of patent applications or the citations per patents at each DOE FFRDC in each year. Both the count of patents and the citations per patents are normalized to control for differences across technological classes, as described above. Because we believe that the "patent production function" at the laboratories will be multiplicative rather than additive-e.g., the policy shifts of the 1980s should have led to a more dramatic absolute increase in patenting at the larger laboratories-we employ the logarithm of normalized patenting as the dependent variable. $^{26}$ We employ both normalized total citations per patent and the normalized ratio excluding self-citations as dependent variables.

We employ a variety of independent variables. To capture the shifting regulatory environment, we employ a dummy variable that denotes whether the annual observation is from 1987 or after. This is roughly when numerous accounts suggest that there was a substantial shift in the seriousness with which the DOE took its mandate to implement technology transfer. Second, we identify the periods when the contractor was changed. As suggested by the Idaho case study, such changes may provide the stimulus to focus real effort on objectives such as technology transfer. We arbitrarily hypothesize that the effect of such changes might be seen from two years before the change through two years

\footnotetext{
${ }^{26}$ Because some laboratories had no patents in certain years, we add one to the total normalized count of patents before computing the logarithm of the dependent variable. We do not employ observations in the citation regressions when laboratories are without any patents.
} 
after. There are a total of fifteen lab-years in the data that fall into such windows, about $8 \%$ of the data points used in the regression.

We also include in the regression a few characteristics of the laboratory or its environment. First, given the wide variation in the size of the laboratories, it is important to control for its scale (either R\&D spending or total patent awards). We also include a variety of time-invariant measures. (These are deleted when we employ fixed effects, i.e., dummy variables for each laboratory.) As discussed above, a strong orientation towards national security or basic science may lead to less technology commercialization. We thus include as independent variables the shares of the laboratories' expenditures classified as national security and basic science-related. (Due to data limitations, we use 1995 values, but these measures appear to be quite constant.) Second, we indicate whether the contractor was a university, and likely to be more familiar with the transfer of early-stage technologies, by employing a dummy variable that assumes the value of unity when this was the case. Third, many reports have claimed that the laboratories' efforts to diversify away from their traditional areas of expertise have led to poor performance. To examine this suggestion, we construct from the patent data a measure of technological "focus": the Herfindahl index of concentration of patenting across technology classes. ${ }^{27}$ We include both the measure of focus as well as the change in our focus measure between the second and first half of the sample period. ${ }^{28}$

The first two columns of Table 5 present the patent regression results. The dramatic increase in patenting associated with the policy shifts of the late $1980 \mathrm{~s}$ is apparent. The results also show that patenting is related to $R \& D$ in the panel as a whole, although this relationship is not present in the "within" or time-series dimension. This is not surprising, given that we know that overall patenting has been rising while R\&D has been falling. Facilities with a greater basic science share have less patenting; the national security share also has a negative coefficient, but it is not statistically significant. More focused laboratories get more patents, all else equal, and those that decreased their focus

27 The Herfindahl index is the sum of the squared shares of patenting in technology classes. Thus it is unity for a laboratory whose patents are all in one class, and a small fraction for laboratories whose patents are distributed across many classes.

${ }_{28}$ We also tried a variety of geographic variables in unreported regressions, but these are consistently insignificant. 
the most have fewer patents. ${ }^{29}$ These effects are statistically and quantitatively significant. Consistent with the benefits that Livermore derived from its association with the University of California's technology transfer offices, facilities run by universities have almost twice as many patents, ceteris paribus, an effect that is highly statistically significant.

For citations, the regressions have low explanatory power; even with laboratory dummies, the $\mathrm{R}^{2}$ is only .138 . The dummy variable indicating that the observation is from 1987 or thereafter is positive but statistically insignificant. This is consistent with Figure 5, which showed a slight but uneven upward trend in normalized citations. Overall, there is no relationship between the level of patenting and the citation intensity. In the fixed-effects version, there is a significant negative relationship, suggesting that the "lower threshold" phenomenon is not completely absent. While the effect of "focus" on citations is insignificant, there is a strong positive effective of the change in focus. That is, those laboratories whose focus decreased substantially saw a significant decline in their (normalized) citation intensity. This is true for all citations (column 3), as well as when self-citations are excluded (column 4). The competition variable has a positive and significant impact in the first two regressions. The point estimate of the magnitude is large, implying that patents applied for during the period of competitive pressures get an additional citation or so relative to what would otherwise be expected. This effect disappears in the fixed-effects regression, which is not surprising given that the variation of the competition variable is mostly across laboratories rather than across time. Finally, we find no statistically significant effect for the national security or basic science share. Thus, these research focuses reduce the amount of patenting, but do not detectably diminish the subsequent commercial impact (as measured by citations) of the patents that are received.

\section{d) Corroboratory Analyses}

One concern with the analyses above is that the patenting patterns may not reflect those in technology commercialization more generally. In particular, the cross-sectional

29 Most of the laboratories decreased their focus between the two sub-periods. Overall, the average Herfindahl fell from .27 to .15 . 
patterns in patenting and citations to these patents may potentially not provide a complete depiction of the relative growth of technology transfer activities at these facilities.

To address the concern, we undertook a similar regression analysis, but using another measure of technology commercialization: the number of new CRADAs approved annually at each laboratory. We used observations between fiscal years 1991 (the first year with a significant number of CRADAs at DOE) and 1997 (with the exception of 1996 , for which we had no data). In order to normalize the data, we employed in all regressions a dummy variable for each fiscal year. In this way, we hoped to control for DOE senior management's shifting emphasis on the importance of CRADAs (as discussed above, this was a major policy focus until the shift in congressional control to the Republican Party). Otherwise, the independent variables are the same as in the two leftmost columns of Table 5. Because the relatively small number of new CRADAs at each facility and year, in the third and forth regressions we instead employ a Poisson regression, which reflects the ordinal, non-negative nature of the dependent variable.

The results of the CRADA regressions are largely consistent with the patent analyses. Not surprisingly, more CRADA activity at a laboratory is associated with higher R\&D expenditures and a lower share of spending devoted to national security or basic science. In one of two regressions, a university contractor is associated with more CRADA activity, which may reflect a greater familiarity with the technology transfer process. The coefficient on the competition variable is highly positive and significant in the basic regressions. The effect once again disappears in the fixed-effects regressions. This reflects the shortness of the panel (if there was contractor turnover during the period at a given laboratory, it is probable that the effects will be felt over much of the period under study and be captured in the laboratory dummy variable). The primary difference from the analyses in Table 5 is that the coefficient measuring laboratory focus is negative (significantly so in one regression) and the change of focus measure is inconsistent in sign.

In addition to the patent and CRADA data, we obtained data on new licenses granted and total license revenues for 13 of the 23 laboratories in 1997. For two of these (Fermi and Princeton), the data indicate essentially no activity. These data are shown in 
Figure 6, along with total citations received in 1995 to all patents owned by the laboratory. ${ }^{30}$ Not surprisingly, the largest laboratories dominate these absolute measures: Lawrence Livermore, Brookhaven, Oak Ridge and Sandia.

Figure 7 present measures that are not dependent on size. The figure depicts licenses and license revenue per dollar of $R \& D$, the growth rate in patenting, and the normalized citations per patent. Here the standouts are much less clear. If we use the criterion of above-average performance in both the licensing and patenting dimensions, the winners are Ames, Livermore, Idaho, Oak Ridge, and Savannah River. Los Alamos and the Stanford Linear Accelerator are relatively poor performers.

Despite the small number of observations, we ran a few diagnostic regressions with these data. Each of the indicators shown in Figure 7 was regressed on the change in the technological focus measure, a competition measure, the national security share, and a dummy for being in a modestly large metropolitan area. ${ }^{31}$ In the unreported results, the coefficient on the competition variable is positive, but never statistically significant. The change in the focus variable has an effect that is positive for all four indicators, but is marginally statistically significant only for citation intensity. The national security share is negative for all four indicators, but not statistically significant. Location in a metropolitan area has no significant effect. These results are at least broadly consistent with the patent- and CRADA-based measures, and address some of the concerns about the generality of these measures.

\section{6) Conclusions}

This paper has examined the commercialization of publicly funded research that is pursued in a little-studied but important environment, the national laboratory. The empirical and case study analyses suggest that the policy reforms of the 1980 s had a dramatic and positive effect on technology commercialization: patenting activities sharply increased, with little evidence of degradation in patent quality. The effects appear to be stronger in settings where the danger of bureaucratic inference was lower,

\footnotetext{
30 The National Renewable Energy Research Laboratory is included in the figure because of its significant patenting activity, even though we do not have licensing information.

31 For the cross-sectional analysis, the "competition" dummy is set to unity if the laboratory contract has ever been subject to competition, even if such competition occurred outside the time period of our analysis. The "metropolitan" dummy was set to unity for laboratories near SMSAs or CMSAs with a population of one million or more.
} 
such as when there was turnover of contractors. Despite the very different activities and performance measures here, the results are consistent with the earlier literature on the impact and determinants of the decision to privatize public sector activities.

It is important to acknowledge this paper's limitations. First, the data we have had had to work with is limited. Ideally, we would have had measures of commercialization other than patents, citations, and CRADAs over an extended period at a variety of facilities. Second, national laboratories play a number of roles, of which producing technology for the commercial sector is only one. We have not attempted to determine whether commercialization activities had either a detrimental or positive effect on these other missions. Third, we have analyzed only the contractor-operated laboratories at one agency, the U.S. Department of Energy. Comparing the experiences of facilities operated by different agencies, employing different organizational structures, and in different countries would all be logical extensions of this work.

Despite these limitations, this paper raises a variety of implications. We will highlight two of these. First, it challenges many of the assumptions implicit in earlier assessments of the national laboratories. The striking improvement in the measures of commercial activities at the laboratories, especially when compared to the experience of the universities, stands in contrast to the negative tone in many discussions such as the "Galvin Report" [Task Force, 1995]. The apparent importance of limiting the distortionary effects of political interference, while in keeping with the academic works on privatization, has not been heavily emphasized in many of the government studies.

More generally, this paper serves to highlight the fertile opportunities at the intersection between the economics of technological change and organizational economics. The different ways in which public and private $R \& D$ can be organized, and the implications of these decisions on the rate and direction of technological change, is a rich area for future research. 


\section{References}

Alchian, Armen, 1965, "Some Economics of Property Rights," Il Politico, 30, 816-829.

Barberis, Nicholas, Maxim Boycko, Andrei Shleifer, and Natalia Tsukanova, 1996, "How Does Privatization Work? Evidence from the Russian Shops," Journal of Political Economy, 104, 764-790.

Berman, Evan M., 1997, “Cooperative Research and Development Agreements," in Yong S. Lee, editor, Technology Transfer and Public Policy, Westport, Connecticut, Quorum Books, pp. 159-171.

Boycko, Maxim, Andrei Shleifer, and Robert Vishny, 1995, Privatizing Russia, Cambridge, MIT Press.

Bozeman, Barry, and Michael Crow, 1991, "Technology Transfer from U.S. Government and University R\&D Laboratories," Technovation, 11, 231-246.

Branscomb, Lewis M., 1993, "National Laboratories: The Search for New Missions and New Structures," in Lewis M. Branscomb, editor, Empowering Technology: Implementing a U.S. Strategy, Cambridge, MIT Press, pp. 103-131.

Cohen, Linda R., and Roger G. Noll, 1996, "The Future of the National Laboratories," Proceedings of the National Academy of Sciences, 93, 12678-12685.

D'Souza, Juliet, and William L. Megginson, 1998, "The Financial and Operating Performance of Privatized Firms During the 1990s," Unpublished working paper, University of Oklahoma.

Forman, Howard I., 1957, Patents: Their Ownership and Administration by the United States Government, New York, Central Book Company.

Glaeser, Edward L., Hedi D. Kallal, José A. Scheinkman, and Andrei Shleifer, 1992, "Growth in Cities," Journal of Political Economy, 100, 1126-1152.

Gompers, Paul A., and Josh Lerner, 1999, The Venture Capital Cycle, Cambridge, MIT Press, forthcoming.

Ham, Rose Marie, and David C. Mowery, 1998, "Improving the Effectiveness of PublicPrivate R\&D Collaboration: Case Studies at a U.S. Weapons Laboratory," Research Policy, 2, 661-675.

Hart, David M., 1998, Forged Consensus: Science, Technology and Economic Policy in the United States, 1921-1953, Princeton, Princeton University Press.

Henderson, Rebecca, Adam Jaffe, and Manuel Trajtenberg, 1998, "Universities as a Source of Commercial Technology: A Detailed Analysis of University Patenting, 1965-1988," Review of Economics and Statistics, 80, 199-127. 
Jaffe, Adam B., 1989, "Real Effects of Academic Research," American Economic Review, 76, 98-1001.

Jaffe, Adam B., Michael S. Fogarty, and Bruce A. Banks, 1998, "Evidence from Patents and Patent Citations on the Impact of NASA and Other Federal Labs on Commercial Innovation," Journal of Industrial Economics, 46, 183-205.

Jaffe, Adam B., Manuel Trajtenberg, and Rebecca Henderson, 1993, "Geographic Localization of Knowledge Spillovers as Evidenced by Patent Citations," Quarterly Journal of Economics, 108, 577-598.

Lang, Larry, and René Stultz, 1994, "Tobin's q, Diversification, and Firm Performance," Journal of Political Economy, 102, 1248-1280.

Lawler, Andrew, 1996, "DOE to Industry: So Long, Partner," Science, 274 (October 4) 24-26.

Lerner, Josh, 1995, "Venture Capitalists and the Oversight of Private Firms," Journal of Finance, 50, 301-318.

Lerner, Josh, 1999, "The Government as Venture Capitalist: The Long-Run Impact of the SBIR Program," Journal of Business, forthcoming.

López-de-Silanes, Florencio, Andrei Shleifer, and Robert W. Vishny, 1997, "Privatization in the United States," Rand Journal of Economics, 28, 447-471.

Markusen, Ann, and Michael Oden, 1996, "National Laboratories as Business Incubators and Region Builders," Journal of Technology Transfer, 21, 93-108.

Megginson, William L., Robert C. Nash, and Mathias van Randerborgh, 1994, "The Financial and Operating Performance of Newly Privatized Firms," Journal of Finance, 49, 403-452.

National Science Board, 1998, Science and Technology Indicators-1998, Washington, Government Printing Office.

Nelson, Richard R., 1959, "The Simple Economics of Basic Scientific Research," Journal of Political Economy, 67, 297-306.

Neumeyer, Frederik, and John C. Stedman, 1971, The Employed Inventor in the United States: R\&D Policies, Law, and Practice, Cambridge, MIT Press.

Roessner, J. David, and Anne Wise, 1993, "Patterns of Industry Interaction with Federal Laboratories," Working Paper \#9302, School of Public Policy, Georgia Institute of Technology. 
Scharfstein, David, and Jeremy Stein, 1997, "The Dark Side of Internal Capital Markets: Divisional Rent-Seeking and Inefficient Investment," National Bureau of Economic Research Working Paper \#5969.

Shleifer, Andrei, and Robert W. Vishny, 1994, "Politicians and Firms," Quarterly Journal of Economics, 109, 995-1025.

Stephan, Paula, 1996, "The Economics of Science," Journal of Economic Literature, 34, 1199-1235.

Task Force on Alternative Futures for the Department of Energy National Laboratories, 1995, Alternative Futures for the Department of Energy National Laboratories, Washington, U.S. Department of Energy.

U.S. Department of Justice, 1947, Investigation of Government Patent Practices and Policies: Report and Recommendations of the Attorney General to the President, Washington, U.S. Government Printing Office.

U.S. Energy Research and Development Administration, 1976, The Patent Policies Affecting ERDA Energy Programs, ERDA-76-16, Washington, U.S. Energy Research and Development Administration.

U.S. General Accounting Office, 1993, Technology Transfer: Implementation of CRADAs at NIST, Army, and DOE, GAO/T-RCED-93-53, Washington, U.S. General Accounting Office.

U.S. General Accounting Office, 1996a, Federal Research: Information on Fees for Selected Federally Funded Research and Development Centers, GAO/RCED-9631FS, Washington, U.S. General Accounting Office.

U.S. General Accounting Office, 1998, Department of Energy: Uncertain Progress in Implementing National Laboratory Reforms, GAO/RCED-98-197, Washington, U.S. General Accounting Office.

U.S. House of Representatives, 1945, The Second Report of the National Patent Planning Commission, Document $\# 22,79^{\text {th }}$ Congress, $1^{\text {st }}$ Session, January 9.

U.S. Office of Technology Assessment, 1993, Defense Conversion: Redirecting $R \& D$, OTA-ITE-552, Washington, Government Printing Office.

Vickers, John, and George Yarrow, 1988, Privatization: An Economic Analysis, Cambridge, MIT Press.

White House Science Council, Federal Laboratory Review Panel, 1983, Report of the Federal Laboratory Review Panel, Washington, White House Science Council. 


\section{Sources of Figures and Tables ${ }^{32}$}

Figure 1: Data on federal and total R\&D between 1960 and 1997 are from National Science Board [1996, 1998]. Federal R\&D data between 1955 and 1969 are from U.S. National Science Foundation [various years], and are obligations (not actual spending, as elsewhere in the figure) for each fiscal year (instead of calendar years). Federal R\&D for 1953 and 1954 and total R\&D between 1953 and 1959 are from U.S. Department of Commerce, Bureau of the Census [1975]. All data before 1953 are from National Academy of Sciences [1952]. Data from 1953 and before is less precise than in later years.

Figure 2: All data between 1960 and 1997 are from National Science Board [1996, 1998]. All data between 1955 and 1959 are from U.S. National Science Foundation [various years], and are obligations (not actual spending, as elsewhere in the figure) for each fiscal year (instead of calendar years).

Figure 3: Data on R\&D at DOE FFRDCs between fiscal years 1987 and 1993 are from National Science Board [1998] and between fiscal years 1981 and 1986 are from U.S. National Science Foundation [1998]. Data on successful patent applications at DOE FFRDCs are based on a database compiled by the DOE's Office of Scientific and Technical Information [1998], as described in Section 5(a)(ii) of the paper.

Figure 4: Data on R\&D at DOE FFRDCs between fiscal years 1987 and 1993 and academic R\&D between 1981 and 1993 are from National Science Board [1998]. Data on R\&D at DOE FFRDCs between fiscal years 1981 and 1986 are from U.S. National Science Foundation [1998]. Data on successful patent applications derived from DOE FFRDCs are based on a database compiled by the DOE's Office of Scientific and Technical Information [1998], as described in Section 5(a)(ii) of the paper. Data on successful patent applications derived from universities are based on a tabulation of the NBER/Case Western Reserve patents database.

Figure 5: Data on successful patent applications derived from DOE FFRDCs are based on a database compiled by the DOE's Office of Scientific and Technical Information [1998], as described in Section 5(a)(ii) of the paper. The analysis is restricted to the fifteen FFRDCs with at least 50 successful patent applications filed between 1977 and 1993 (and awarded by the end of 1996). Data on citations to the patents and the information used to normalize patents and citations are based on a tabulation of the NBER/Case Western Reserve patents database.

Figure 6: Data on new licenses and licensing revenues for DOE FFRDCs in fiscal year 1997 are from U.S. Department of Energy, Office of the General Counsel [1998]. Data on citations to the DOE FFRDC patents and the information used to normalize citations are based on a database compiled by the DOE's Office of Scientific and Technical

${ }^{32}$ References to sources only cited in this section are included in the "Data Sources" listing, and not in the main "References" listing. 
[1998] and in fiscal years 1997 are from U.S. National Science Foundation [1998]. Data on successful patent applications derived from DOE FFRDCs are based on a database compiled by the DOE's Office of Scientific and Technical Information [1998], as described in Section 5(a)(ii) of the paper. The patent growth rate is the average annual rate estimated from a regression using observations between 1981 and 1993. Data on citations to the patents and the information used to normalize patents and citations are based on a tabulation of the NBER/Case Western Reserve patents database.

Table 1: Data on energy agency-funded R\&D (which includes spending by the U.S. Atomic Energy Commission, the U.S. Energy Research and Development Administration, and the DOE) at DOE FFRDCs between fiscal years 1970 and 1997 and on total R\&D at DOE FFRDCs between fiscal years 1987 and 1995 are from National Science Board [1996, 1998]. Data on energy agency-funded R\&D at DOE FFRDCs between fiscal years 1955 and 1969 are from U.S. National Science Foundation [various years], and are obligations (not actual spending, as elsewhere in the table). Data on total R\&D at DOE FFRDCs between fiscal years 1981 and 1986 and in fiscal years 1996 and 1997 are from National Science Foundation [1998]. Data on technology transfer activities in fiscal year 1997 are from U.S. Department of Energy, Office of the General Council [1998]. Data on technology transfer activities between fiscal years 1987 and 1996 are from U.S. Department of Commerce, Office of Technology Administration [various years]. Data on technology transfer activities between fiscal years 1963 and 1976 are from Federal Council for Science and Technology [various years]. No technology transfer data are available between fiscal years 1977 and 1986. No CRADAs were signed by DOE FFRDCs prior to fiscal year 1990. Licensing and CRADA data between fiscal years 1987 and 1996 include some activity by facilities operated by the DOE. Definitions of various technology transfer activities may be inconsistent across different years and facilities.

Table 2: The technology transfer data are compiled from U.S. Department of Energy, Office of Defense Programs [1998], http://www.llnl.gov/IPandC/About/ipacAnn.html, and personal communications with DOE officials. The data series on the two FFRDCs have been selected to be as comparable as possible, but differences remain. For instance, the count of INEEL licenses only includes those transactions where royalties or fees have been collected by INEEL by the end of fiscal year 1998 .

Table 3: Information on the dates of certification and decertification as a FFRDC, the contractors who managed the facilities, and the periods for which they were responsible for the facilities was gathered from Burke and Gray [1995], U.S. General Accounting Office [1996b], the historical information on many facilities' web sites, and a variety of news stories in LEXIS/NEXIS. The Herfindahl index of patent class concentration is 
computed using patents applications between 1977 and 1995 awarded by the end of 1996 , and is based on a database compiled by the DOE's Office of Scientific and Technical Information [1998], as described in Section 5(a)(ii) of the paper. The population of the nearest SMSA or CMSA is from a variety of publications summarizing the 1980 Census of Population and Housing. The fractions of R\&D at each FFRDC in fiscal year 1995 devoted to national security and basic science were from U.S. Department of Energy, Laboratory Operations Board [1996]. The share of all U.S. venture capital disbursements in 1988 going to companies in the state (calculated using the number of companies funded) is based on a special tabulation of Venture Economics' Venture Intelligence Database. We determine whether the contract for the facility was ever competitively awarded from U.S. General Accounting Office [1996b]. Data on new licenses and licensing revenues for DOE FFRDCs in fiscal year 1997 are based on U.S. Department of Energy, Office of the General Counsel [1998]. Data on R\&D at DOE FFRDCs in fiscal year 1995 are from National Science Board [1998].

Table 4: Data on successful patent applications (awarded by the end of end of 1996) derived from DOE FFRDCs are based on a database compiled by the DOE's Office of Scientific and Technical Information [1998], as described in Section 5(a)(ii) of the paper. Data on citations to the patents are based on a tabulation of the NBER/Case Western Reserve patents database. The count of CRADAs in fiscal years 1991 through 1994 (which only includes awards made under the aegis of the Defense Programs, Energy Efficiency, and Energy Research program offices) is from U.S. Department of Energy [1995]. The fiscal year 1995 and 1997 data, which include all DOE FFRDC CRADAs, are from Technology Transfer Business [1998] and U.S. Department of Energy, Office of the General Counsel [1998] respectively.

Table 5: See sources for Tables 3 and 4. In addition, data on R\&D at DOE FFRDCs between fiscal years 1987 and 1993 are from National Science Board [1998] and between fiscal years 1981 and 1986 are from U.S. National Science Foundation [1998]. The information used to normalize patents and citations are based on a tabulation of the NBER/Case Western Reserve patents database.

Table 6: See sources for Tables 3 and 4. In addition, data on R\&D at DOE FFRDCs between fiscal years 1991 and 1995 are from National Science Board [1998] and in fiscal years 1997 from U.S. National Science Foundation [1998]. 


\section{Data Sources [If Not in Main Bibliography]}

Burke, Mary V., and Jennifer R. Gray, 1995, “Annotated List of Federally Funded Research and Development Centers," http://www.nsf.gov/sbe/srs/s4295.

Federal Council for Science and Technology, various years, Annual Report on Government Patent Policy (also known as Report on Government Patent Policy), Washington, Government Printing Office.

National Academy of Sciences, 1952, Applied Research in the United States, Washington, National Academy Press.

National Science Board, 1996, Science and Technology Indicators-1996, Washington, Government Printing Office.

Technology Transfer Business, 1998, "Federal Research \& Development Laboratories," http://www ded state ne us/fedlab1 html.

U.S. Department of Commerce, Bureau of the Census, 1975, Historical Statistics of the United States, Washington, Government Printing Office.

U.S. Department of Commerce, Office of Technology Administration, various years, Technology Transfer Under the Stevenson-Wydler Innovation Act, Washington, Government Printing Office.

U.S. Department of Energy, 1990, Multiprogram Laboratories: 1979 to 1988, A Decade of Change, Washington, U.S. Department of Energy.

U.S. Department of Energy, 1995, "List of CRADA Activity," Unpublished tabulation.

U.S. Department of Energy, Laboratory Operations Board, 1996, Strategic Laboratory Missions Plan-Phase I, Washington, U.S. Department of Energy.

U.S. Department of Energy, Office of Defense Programs, 1998, "Licensing of Intellectual Property at Defense Program Laboratories and Plants in Fiscal Year 1997," Unpublished tabulation.

U.S. Department of Energy, Office of Procurement and Assistance Management, 1998, "DOE Procurement and Assistance Data System (PADS) On-Line Database," http://www.pr.doe.gov/pads.html.

U.S. Department of Energy, Office of Scientific and Technical Information, 1998, "DOE Patents Database," Unpublished tabulation. 
U.S. Department of Energy, Office of the General Counsel, 1998, "Technology Transfer Activities, Fiscal Years 1997 through 1999," Unpublished tabulation.

U.S. General Accounting Office, 1994, National Laboratories: Are Their R\&D Activities Related to Commercial Product Development?, GAO/PMED-95-2, Washington, U.S. General Accounting Office.

U.S. General Accounting Office, 1996b, Department of Energy: Contract Reform is Progressing, but Full Implementation Will Take Years, GAO/RCED-97-18, Washington, U.S. General Accounting Office.

U.S. National Science Foundation, various years, Federal Funds for Research and Development, Washington, U.S. Government Printing Office.

U.S. National Science Foundation, 1998, "Federal Obligations for Research and Development to Federally Funded Research and Development Centers (FFRDCs), by Individual FFRDC: Fiscal Years 1980-1997,' Unpublished tabulation. 


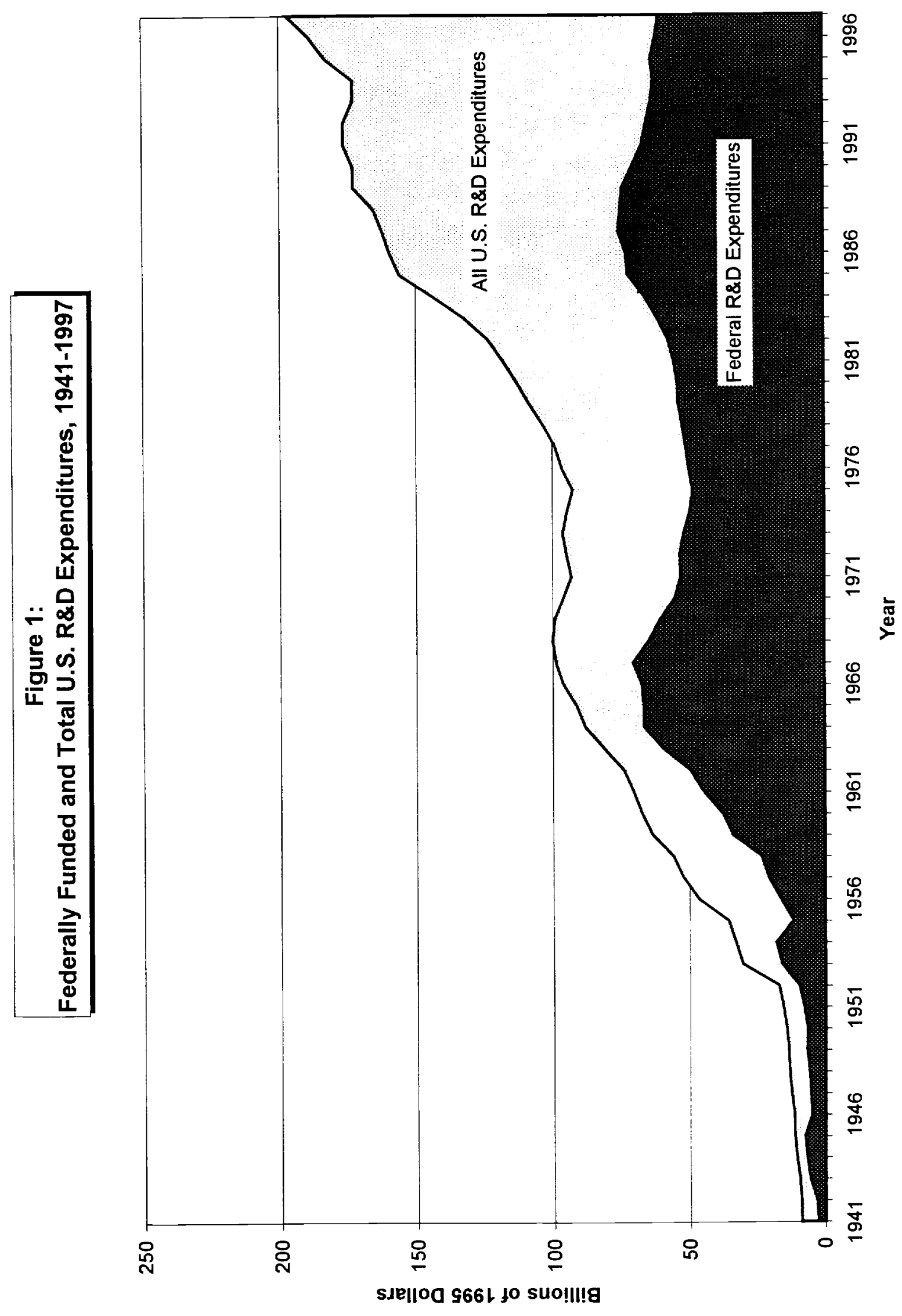




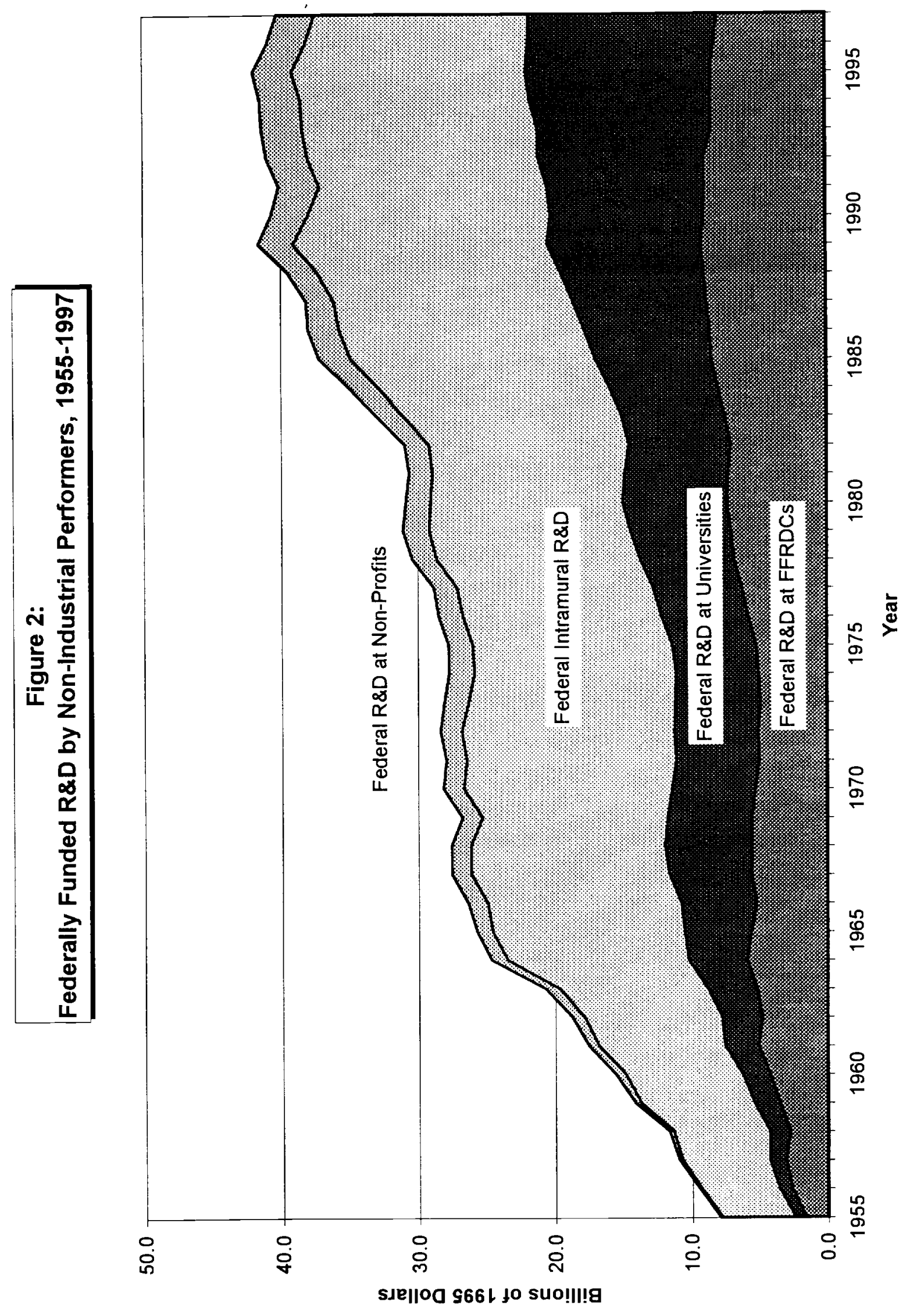




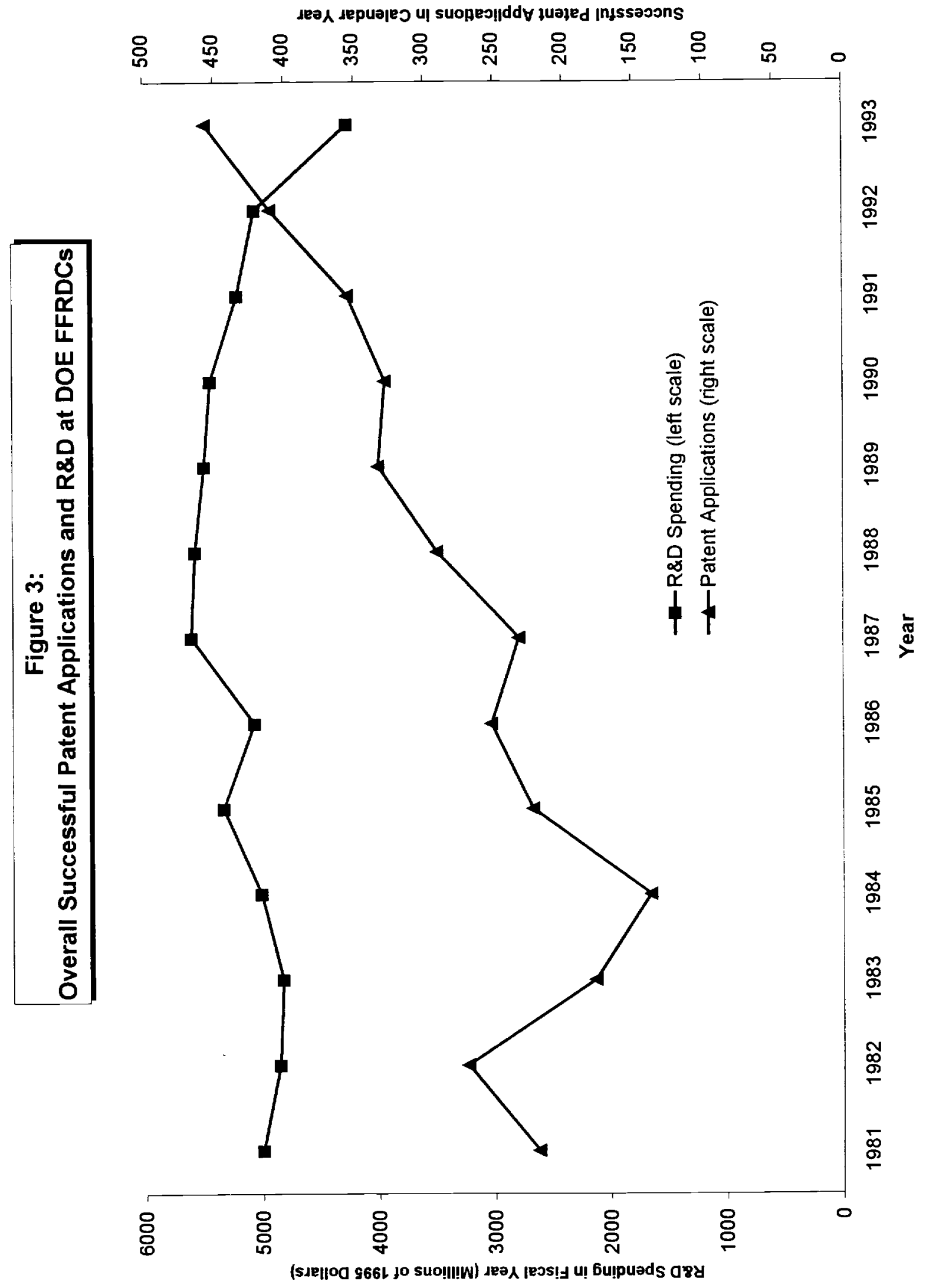




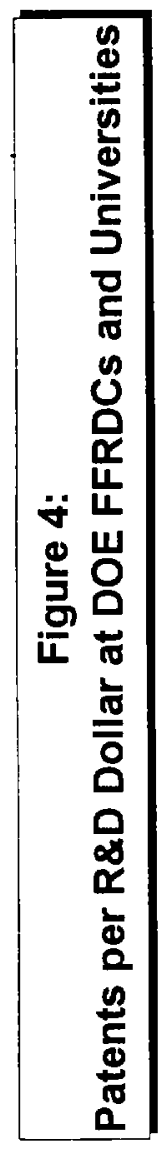

4

\%ั

ัั

ฐ

용

\&

$\stackrel{\infty}{\infty}$

兽

$\stackrel{\mathscr{0}}{\stackrel{\mathscr{O}}{\circ}}$

吕

品

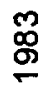

ัㅗำ

욤

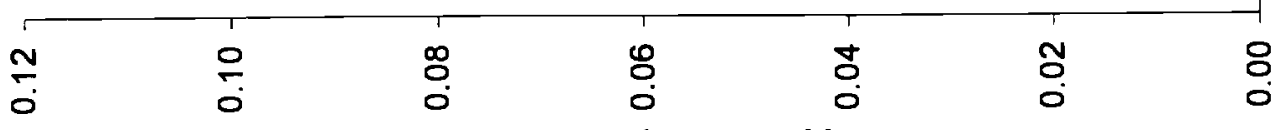

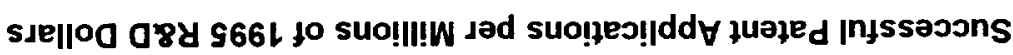




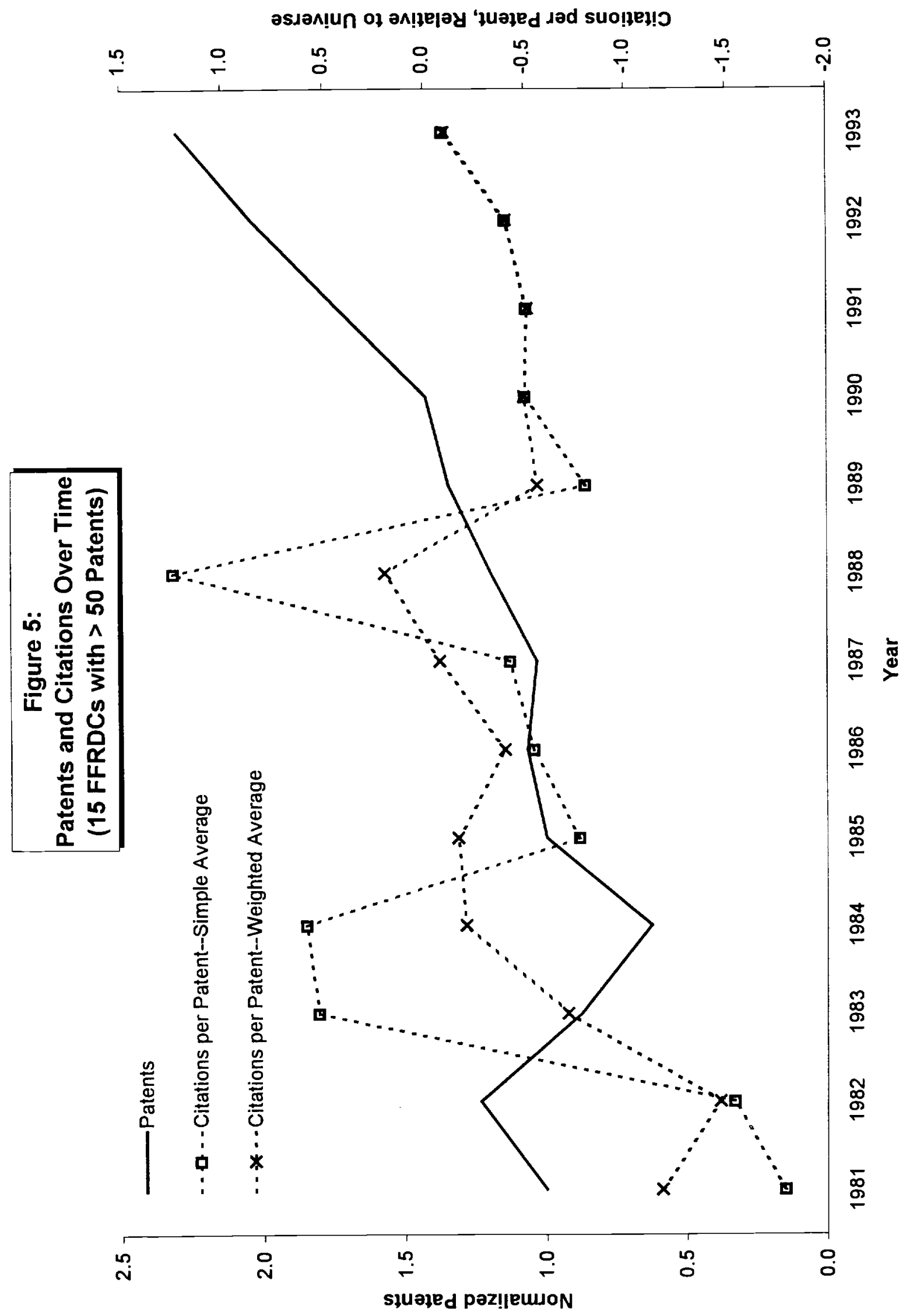



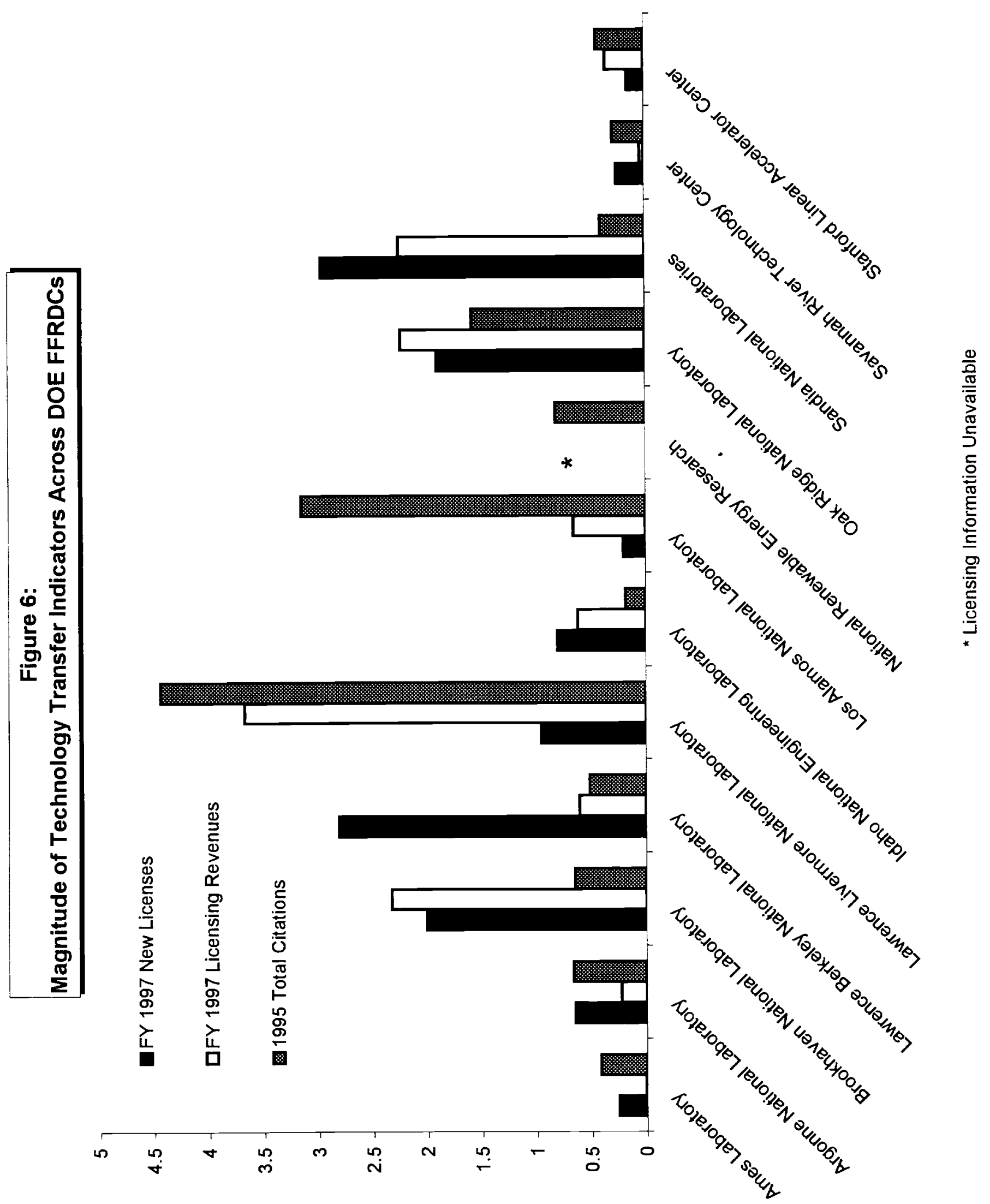

sqeר II sof ueaw of o!jey 


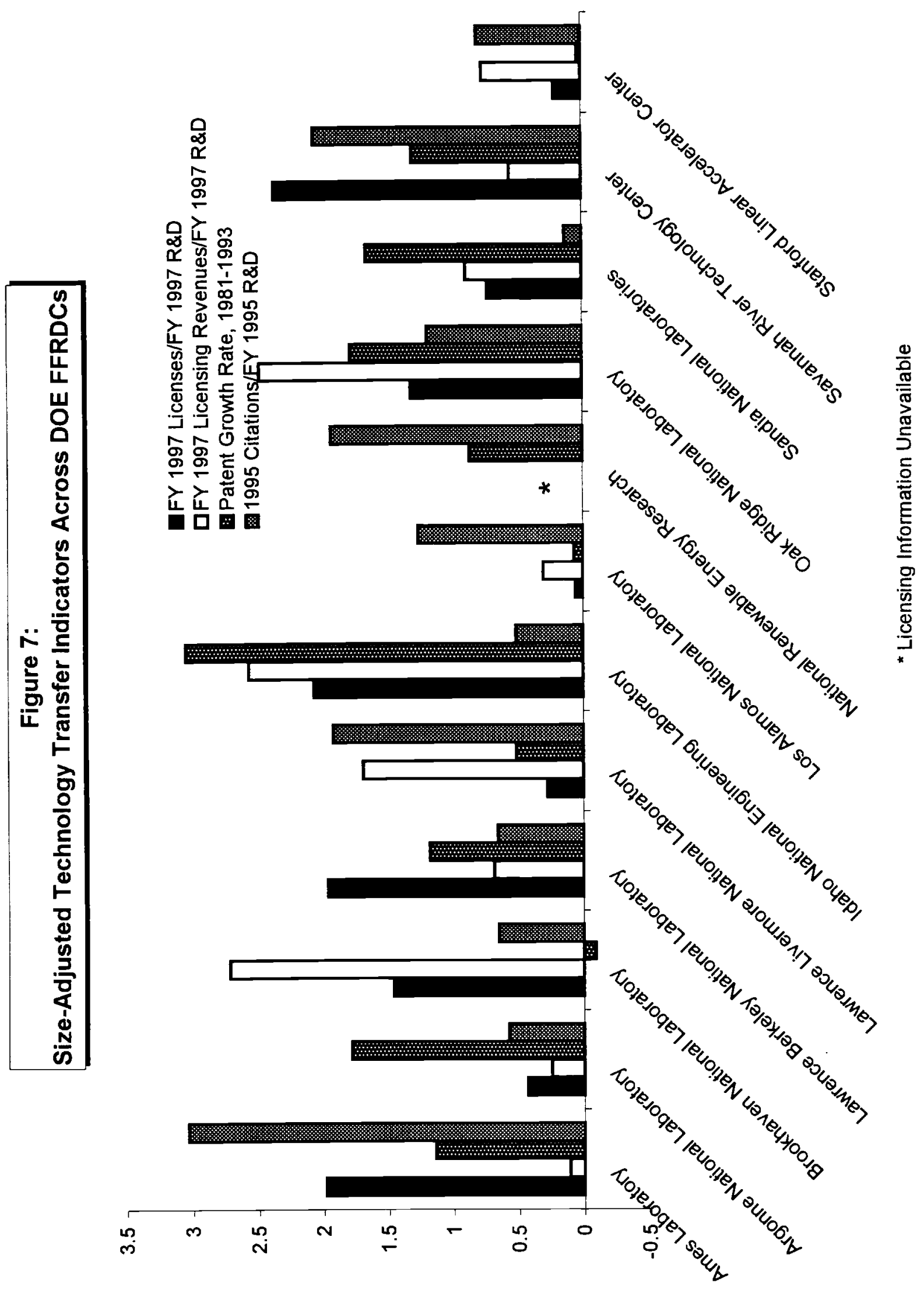

sqeר II $\forall$ JOJ ueaw of o!̣ey 


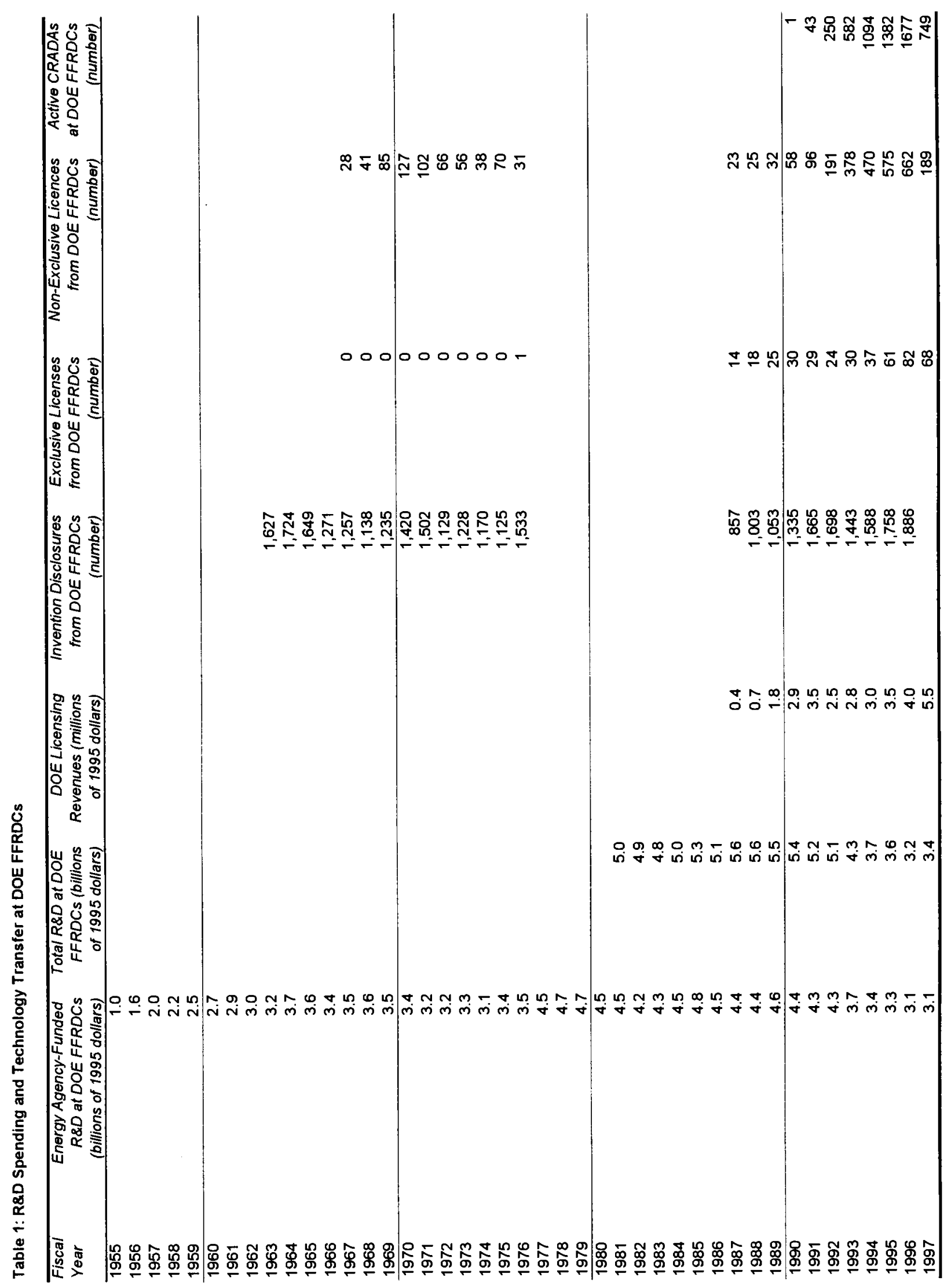




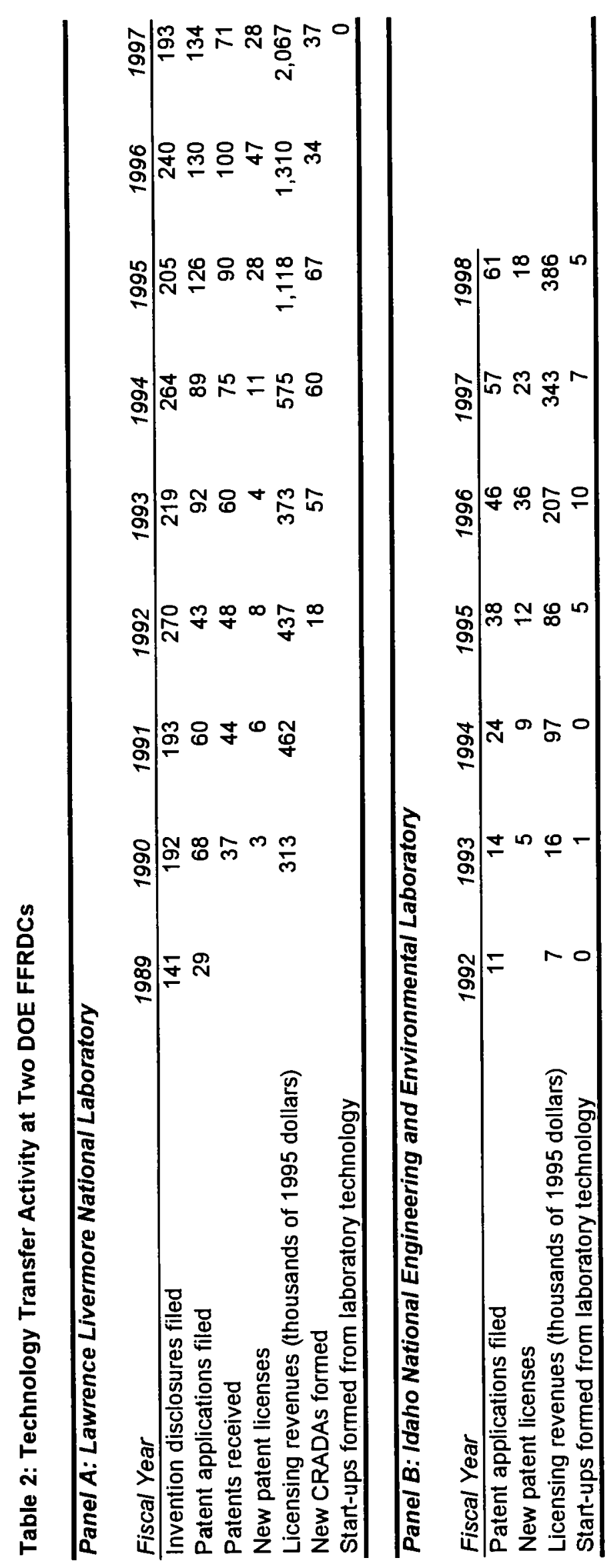




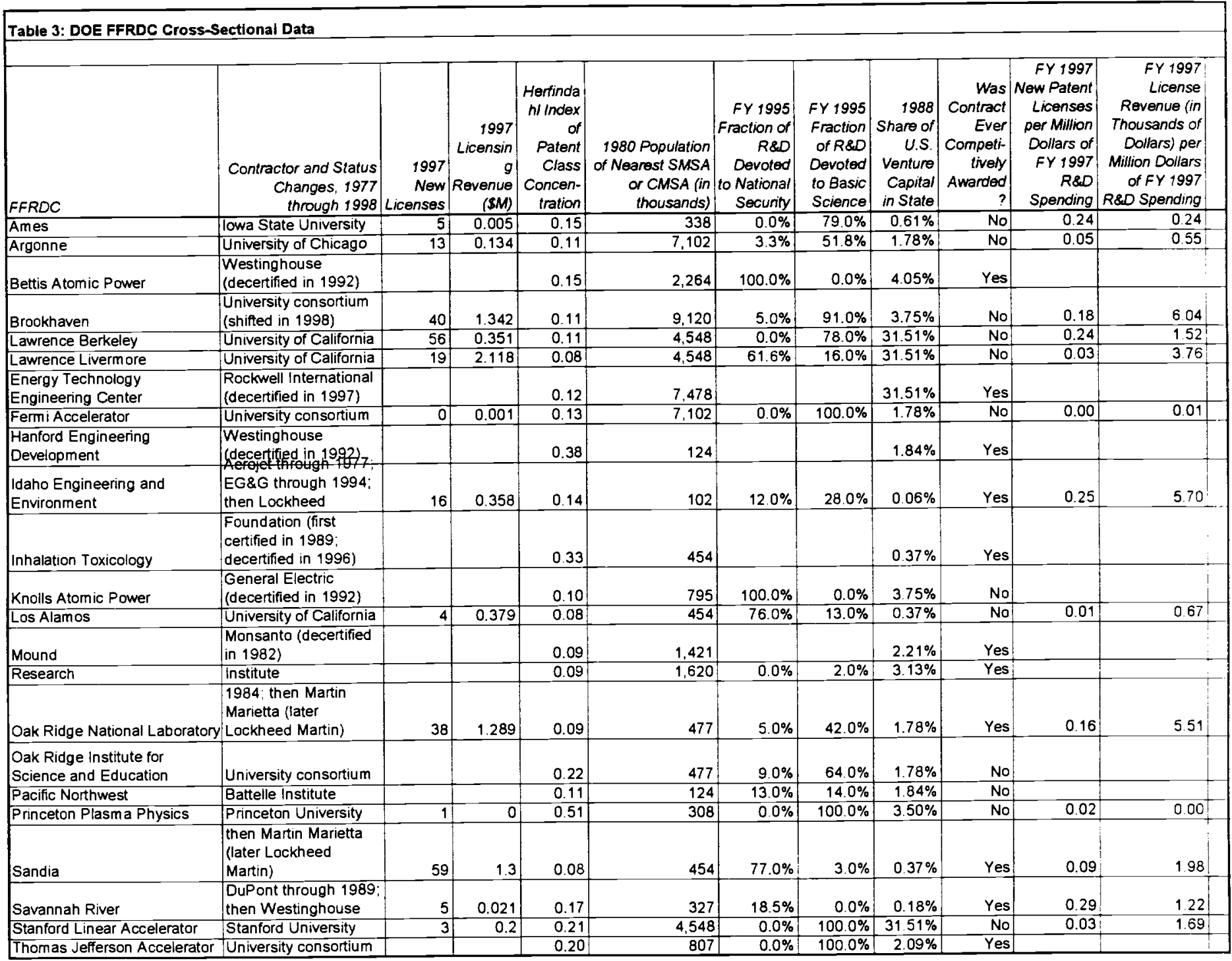




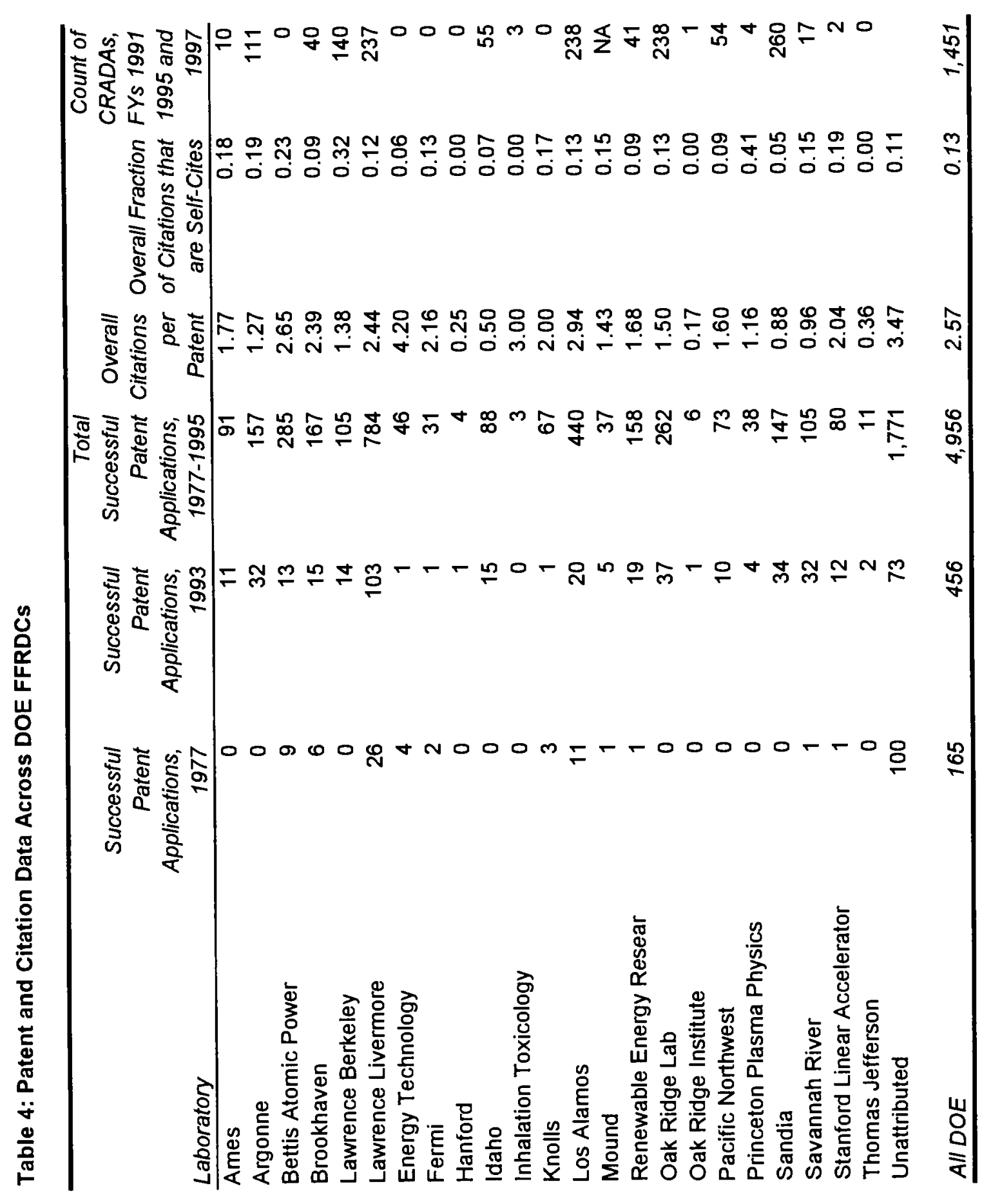




\begin{tabular}{|c|c|c|c|c|c|}
\hline & \multicolumn{5}{|c|}{ Dependent Variable: } \\
\hline & $\begin{array}{r}\text { Logarithm of } \\
\text { Patents } \\
\end{array}$ & $\begin{array}{r}\text { Logarithm of } \\
\text { Patents }{ }^{1}\end{array}$ & $\begin{array}{r}\text { Total Citations per } \\
\text { Patent }{ }^{2} \\
\end{array}$ & $\begin{array}{r}\text { Non-Self- } \\
\text { Citations per } \\
\text { Patent }{ }^{2} \\
\end{array}$ & $\begin{array}{r}\text { Non-Self- } \\
\text { Citations per } \\
\text { Patent } \\
\end{array}$ \\
\hline Independent Variables: & (1) & (2) & (3) & (4) & (5) \\
\hline Logarithm of R\&D in Fiscal Year & $\begin{array}{r}0.223 \\
* \star *(.072)\end{array}$ & $\begin{array}{r}-0.139 \\
(.190)\end{array}$ & & & \\
\hline Logarithm of Patents ${ }^{1}$ & & & $\begin{array}{r}-0.532 \\
* \star(.259)\end{array}$ & $\begin{array}{r}-0.489 \\
* *(.235)\end{array}$ & $\begin{array}{r}-0.936 \\
\star *(.305)\end{array}$ \\
\hline "Competition" & $\begin{array}{l}0.019 \\
(.217)\end{array}$ & $\begin{array}{l}0.172 \\
(.201)\end{array}$ & $\begin{array}{r}1.651 \\
\star \star(.796)\end{array}$ & $\begin{array}{r}1.365 \\
*(.721)\end{array}$ & $\begin{array}{l}0.682 \\
(.800)\end{array}$ \\
\hline "Focus", & $\begin{array}{r}1.471 \\
\star *(.637)\end{array}$ & & $\begin{array}{r}-2.272 \\
(2.309)\end{array}$ & $\begin{array}{r}-2.855 \\
(2.092)\end{array}$ & \\
\hline Change in "Focus"4 & $\begin{array}{r}1.804 \\
* * *(.298)\end{array}$ & & $\begin{array}{r}2.868 \\
* *(1.168)\end{array}$ & $\begin{array}{r}2.377 \\
* *(1.058)\end{array}$ & \\
\hline $\begin{array}{l}\text { National Security Share of R\&D } \\
\text { (FY 1995) }\end{array}$ & $\begin{array}{r}-0.192 \\
(.234)\end{array}$ & & $\begin{array}{r}-0.847 \\
(.719)\end{array}$ & $\begin{array}{r}-0.921 \\
(.651)\end{array}$ & \\
\hline $\begin{array}{l}\text { Basic Science Share of R\&D } \\
\text { (FY 1995) }\end{array}$ & $\begin{array}{r}-1.801 \\
* * *(.288)\end{array}$ & & $\begin{array}{r}-1.489 \\
(1.095)\end{array}$ & $\begin{array}{r}-1.470 \\
(.992)\end{array}$ & \\
\hline University Contractor & $\begin{array}{r}1.023 \\
\star * *(.172)\end{array}$ & & $\begin{array}{l}0.960 \\
(.666)\end{array}$ & $\begin{array}{l}0.768 \\
(.603)\end{array}$ & \\
\hline Year $=1987$ or Later & $\begin{array}{r}0.515 \\
* * \star(.102)\end{array}$ & $\begin{array}{r}0.514 \\
\star \star \star \\
(.085)\end{array}$ & $\begin{array}{r}0.680 \\
*(.372)\end{array}$ & $\begin{array}{l}0.321 \\
(.337)\end{array}$ & $\begin{array}{l}0.526 \\
(.345)\end{array}$ \\
\hline Lab Fixed Effects & excluded & $\begin{array}{r}\text { included } \\
\text { significant }\end{array}$ & excluded & excluded & $\begin{array}{r}\text { included } \\
\text { significant }\end{array}$ \\
\hline Number of Observations & 238 & 238 & 244 & 244 & 244 \\
\hline $\mathrm{R}^{2}$ & 0.495 & 0.687 & 0.045 & 0.044 & 0.138 \\
\hline
\end{tabular}

1. Logarithm of (DOE FFRDC patents +1 )/(weighted average number of all patents by field) (see text for more detail)

2. Normalized for truncation and variation in propensity to cite as described in the text.

3. Dummy equal to unity from 2 years before through 2 years after change in contractor.

4. Herfindahl Index of concentration of patents across technology classes.

The change is the difference between the second and first half of the sample period.

Standard errors in parentheses:

* next to the standard error denotes coefficients that are statistically significant at the $90 \%$ level.

* next to the standard error denotes coefficients that are statistically significant at the $95 \%$ level.

*ut next to the standard error denotes coefficients that are statistically significant at the $99 \%$ level. 


\begin{tabular}{|c|c|c|c|c|}
\hline & & & & \\
\hline & $\begin{array}{c}\text { OLS } \\
\text { Logarithm of } \\
\text { New CRADAs } \\
\text { Formed }^{1}\end{array}$ & $\begin{array}{c}\text { OLS } \\
\text { Logarithm of } \\
\text { New CRADAs } \\
\text { Formed }^{1}\end{array}$ & $\begin{array}{c}\text { Poisson } \\
\text { New CRADAs } \\
\text { Formed }\end{array}$ & $\begin{array}{c}\text { Poisson } \\
\text { New CRADAs } \\
\text { Formed } \\
\end{array}$ \\
\hline Independent Variables: & (1) & (2) & (3) & (4) \\
\hline Logarithm of R\&D in Fiscal Year & $\begin{array}{r}0.897 \\
\star \star \star * \\
.132)\end{array}$ & $\begin{array}{r}-0.009 \\
(.202)\end{array}$ & $\begin{array}{r}1.045 \\
\star \star \star \\
(.092)\end{array}$ & $\begin{array}{r}0.768 \\
* * *(.195)\end{array}$ \\
\hline "Competition"2 & $\begin{array}{r}0.649 \\
\star \star(.308)\end{array}$ & $\begin{array}{r}-0.058 \\
(.343)\end{array}$ & $\begin{array}{r}0.401 \\
(.130)\end{array}$ & $\begin{array}{r}-0.232 \\
(.166)\end{array}$ \\
\hline "Focus"3 & $\begin{array}{r}-1.822 \\
(1.120)\end{array}$ & & $\begin{array}{r}-7.492 \\
* \star *(1.853)\end{array}$ & \\
\hline Change in "Focus" & $\begin{array}{l}-0.855 \\
*(.479)\end{array}$ & & $\begin{array}{l}0.295 \\
(.333)\end{array}$ & \\
\hline $\begin{array}{l}\text { National Security Share of R\&D } \\
\text { (FY 1995) }\end{array}$ & $\begin{array}{r}-1.430 \\
\star \\
\star(.549)\end{array}$ & & $\begin{array}{r}-1.495 \\
\star \star \star \\
(.227)\end{array}$ & \\
\hline $\begin{array}{l}\text { Basic Science Share of R\&D } \\
\text { (FY 1995) }\end{array}$ & $\begin{array}{r}-1.680 \\
\star \star \star \\
(.558)\end{array}$ & & $\begin{array}{r}-0.805 \\
* * * \\
* 252)\end{array}$ & \\
\hline University Contractor & $\begin{array}{r}0.694 \\
*(.375)\end{array}$ & & $\begin{array}{l}0.227 \\
(.158)\end{array}$ & \\
\hline Year Fixed Effects & $\begin{array}{r}\text { included } \\
\text { significant }\end{array}$ & $\begin{array}{r}\text { included } \\
\text { significant }\end{array}$ & $\begin{array}{r}\text { included } \\
\text { significant }\end{array}$ & $\begin{array}{r}\text { included } \\
\text { significant }\end{array}$ \\
\hline Lab Fixed Effects & excluded & $\begin{array}{r}\text { included } \\
\text { significant }\end{array}$ & excluded & $\begin{array}{r}\text { included } \\
\text { significant }\end{array}$ \\
\hline Number of Observations & 95 & 104 & 95 & 104 \\
\hline $\mathrm{R}^{2}$ & 0.744 & 0.872 & & \\
\hline Pseudo $\mathrm{R}^{2}$ & & & 0.736 & 0.823 \\
\hline
\end{tabular}

1. Logarithm of (New CRADAs Formed+1) (see text for more detail).

2. Dummy equal to unity from 2 years before through 2 years after change in contractor.

3. Herfindahl Index of concentration of patents across technology classes.

The change is the difference between the second and first half of the sample period.

Standard errors in parentheses:

* next to the standard error denotes coefficients that are statistically significant at the $90 \%$ level.

** next to the standard error denotes coefficients that are statistically significant at the $95 \%$ level

$* * *$ next to the standard error denotes coefficients that are statistically significant at the $99 \%$ level. 